\title{
Hepatitis $C$ virus infection in Irish drug users and prisoners - a scoping review
}

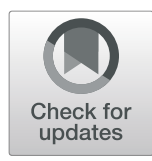

D. Crowley ${ }^{1^{*}}$ (D) R. Murtagh ${ }^{2}$, W. Cullen², J. S. Lambert ${ }^{2,3}$, T. McHugh $^{3}$ and M. C. Van Hout ${ }^{4}$

\begin{abstract}
Background: Hepatitis C infection is a major public health concern globally. In Ireland, like other European countries, people who use drugs (PWUD) and prisoners carry a larger HCV disease burden than the general population. Recent advances in HCV management have made HCV elimination across Europe a realistic goal. Engaging these two marginalised and underserved populations remains a challenge. The aim of this review was to map key findings and identify gaps in the literature (published and unpublished) on HCV infection in Irish PWUD and prisoners.

Methods: A scoping review guided by the methodological framework set out by Levac and colleagues (based on previous work by Arksey \& O'Malley).

Results: A total of 58 studies were identified and divided into the following categories; Epidemiology, Guidelines and Policy, Treatment Outcomes, HCV-related Health Issues and qualitative research reporting on Patients' and Health Providers' Experiences. This review identified significantly higher rates of HCV infection among Irish prisoners and PWUD than the general population. There are high levels of undiagnosed and untreated HCV infection in both groups. There is poor engagement by Irish PWUD with HCV services and barriers have been identified. Prison hepatology nurse services have a positive impact on treatment uptake and outcomes. Identified gaps in the literature include; lack of accurate epidemiological data on incident infection, untreated chronic HCV infection particularly in PWUD living outside Dublin and those not engaged with OST.

Conclusion: Ireland like other European countries has high levels of undiagnosed and untreated HCV infection. Collecting, synthesising and identifying gaps in the available literature is timely and will inform national HCV screening, treatment and prevention strategies.
\end{abstract}

Keywords: HCV, Prisoner, People who use drugs, PWUD, PWID, Irish, Scoping review

\section{Background}

Hepatitis $\mathrm{C}$ virus $(\mathrm{HCV})$ infection is a major public health concern globally. In developed countries iatrogenic transmission of $\mathrm{HCV}$ has been substantially reduced and people who inject drugs (PWID) or have done so in the past are now the main group affected [1-5]. Of the 600, $000 \mathrm{HCV}$ infected people living in Europe an estimated 20,000-30,000 reside in Ireland [6-9]. An estimated 60\% of HCV infections in Ireland remain undiagnosed $[6,10]$.

Ongoing criminalisation of drug users ensure high levels of HCV in prison populations globally. It is estimated that a quarter of the global prison population have been exposed to HCV infection [11-13].

\footnotetext{
* Correspondence: des.crowley@hse.ie

${ }^{1}$ Irish College of General Practitioners, Dublin, Ireland

Full list of author information is available at the end of the article
}

Historically in Ireland, HCV transmission has occurred through infected blood and blood products with the majority of these infections occurring between the 1970s and the early 1990s [14]. Prior to the introduction of routine screening of Irish blood donations (1991), approximately 1700 people were infected through blood and blood products $[6,14]$. HCV infection has been a notifiable disease in Ireland since 2004. Between 2004 and 2017, 14,107 cases were notified by the diagnosing laboratory with a peak in $2007(n=1539)$ [15]. In recent years there has been a decrease in cases notified with the number of new cases stabilising [15]. In 2012, the case definition was altered to specifically exclude resolved cases of $\mathrm{HCV}$ infection which may explain part of the reduction in the number of cases notified after this date [6]. Although there were no notifications of $\mathrm{HCV}$

(c) The Author(s). 2019 Open Access This article is distributed under the terms of the Creative Commons Attribution 4.0 International License (http://creativecommons.org/licenses/by/4.0/), which permits unrestricted use, distribution, and 
infection prior to 2004, diagnostic data from the National Virus Reference Laboratory (NVRL) estimates that approximately 10,000 individuals were diagnosed with HCV infection between 1989 and 2004 [6]. A 2012 mathematical modelling study estimated the national prevalence of chronic hepatitis $\mathrm{C}$ in the Irish general population as $0.5-1.2 \%(20,000-50,000)$ [6]. A more recent lab-based residual sera study reported a prevalence estimate of $0.5-0.7 \%(20,000-30,000)$ [9]. Genotypes 1 and 3 are the types most commonly seen in Ireland and are distributed 55 and $45 \%$ respectively [16]. These are estimates of prevalence and the true prevalence rate in Ireland is unknown. There is no general screening of the population to determine prevalence rates with most studies only assessing the prevalence within specific risk groups $[17,18]$.

The estimates of prevalence however do indicate that in the general population the prevalence of hepatitis $C$ is low, and most cases are from a defined risk group mainly PWID, people who received unscreened blood or blood products and people who were born in hepatitis $\mathrm{C}$ endemic countries [10].

Hepatitis $\mathrm{C}$ related morbidity and mortality continues to increase in Ireland, with increased hospital admission for, HCV related end stage liver disease (ESLD), hepatocellular cancer (HCC) and liver transplant [10]. This increase is likely related to the fact that the peak incidence of HCV infection in Irish PWID was in the late 1990s, and those infected during this period are now developing ESLD or HCC [19].

Since 2010 risk factor information has been available for $57 \%$ of notified chronic HCV cases in Ireland [6, 10, 14]. This data show injecting drug use (IDU) is the most common risk factor reported (80\%), followed by possible sexual exposure (5\%), receipt of blood or blood products (4\%), vertical transmission (2\%) and tattooing or body piercing (1\%) (3). No risk factor was identified in $7 \%$ of notified cases [14].

The most significant risk factor for the transmission of $\mathrm{HCV}$ infection in Ireland is through injecting heroin. Capture-recapture studies carried out between 2001 and 2014 indicate that there are a significant number of problem opiate users in Ireland. The national point prevalence estimate of opiate users in 2014 was 18,988 , giving a rate of 6.18 per thousand population aged 1564 years (95\% CI: 6.09-6.98). The prevalence of problem opiate use in Ireland has stabilised but remains amongst the highest in Europe [20]. Recent national trends indicate that the incidence of injecting opiates is declining [21]. There has been a steady decline in the total number of new entrants to treatment reporting opiates as their main problem drug with a drop from $58.1 \%$ in 2010 to $47 \%$ in 2016 [22]. The percentage who had ever injected among new treatment entrants for problem opiate use has also decreased significantly over time from $71 \%$ in 2004 to $64 \%$ in 2015 [21].

The Irish government introduced opiate substitution therapy (OST) and needle exchange programmes in Ireland in 1989 in response to an increasing HIV prevalence in PWID. OST is now provided nationally through a network of specialised HSE outpatient treatment clinics/satellite clinics, specially trained level 1 and 2 general practitioners in the community and prisons [23]. All OST patients are registered on a central treatment list (CTL). The number of clients on this list has increased each year since 2006 and there are now over 10, 000 people on OST in Ireland [23].

The ongoing criminalisation of drug users in Ireland impacts on the levels of HCV infection in Irish prison populations. Over $60 \%$ of the 3400 prisoners incarcerated on a daily basis have a history of drug use with over a quarter reporting a history of IDU [13]. It is recognised that the majority of Irish prisoners come from marginalised communities with high levels of poverty, social deprivation, unemployment, illiteracy, physical and mental illness including addiction and blood borne virus (BBV) infections [24]. Like other prisoners, Irish inmates are identified as a hard to reach group for medical interventions and have poor access and uptake of traditional community medical services [24, 25].

Like other European countries, Ireland is upscaling HCV screening and treatment services [14, 26-28]. Direct acting anti-virals (DAA), mobile elastography and the movement of $\mathrm{HCV}$ treatment in the community, coupled with less restrictive $\mathrm{HCV}$ treatment guidelines have revolutionised the HCV treatment landscape [2932]. Ireland's national treatment program has signed up to the Global Health Sector Strategy on viral hepatitis for 2016-2020. The program aims to eliminate $\mathrm{HCV}$ as a major public health threat in Ireland by 2030 [33]. The roll out of new highly effective treatment in Ireland offers an exciting opportunity to achieve this goal yet many challenges to up scaling HCV screening and treatment to effective levels still remain. Understanding the burden of HCV disease and the barriers to screening, assessment, treatment and prevention in people who use drugs (PWUD) and prisoners in an Irish context is imperative in the planning and implementation of an effective national HCV strategy.

This scoping review collects and summarises the literature on HCV infection in PWUD and prisoners residing in Ireland. This review can, act as a baseline by which to monitor progress, support focused action and inform national and international public health $\mathrm{HCV}$ elimination strategies that target PWUD and prisoners as key at risk populations. This review also aims to identify gaps in the Irish-based $\mathrm{HCV}$ literature related to 
PWUD and prisoners and assess how these impacts on strategy development and service delivery.

\section{Methods}

This scoping review of HCV infection in drug users and prisoners in Ireland was conducted by applying the methodological framework set out by Levac and colleagues which was based on prior work by Arksey \& O'Malley [34, 35]. The steps include; identifying the research question, identifying all relevant studies, selecting significant studies, charting the relevant data and then summarising and reporting the results. The rationale for using this methodology was to determine what is known about HCV infection in Irish PWUD and prisoners by reviewing all available literature (quantitative, qualitative, guidelines and policy documents) on these two groups and to map the key findings and concepts emerging from this body of literature. A further aim was to map gaps in the literature which will inform future research.

A broad search strategy was conducted in order to identify all relevant studies. Databases searched included PubMed, Science Direct, EMBASE, PsycINFO, Cochrane library and Medline. No limits were placed on dates. The key terms we used for this search were the MeSH terms, "hepatitis C" and ["prison" or "prisoner"] and "drug users" and "Ireland" or similar non-MeSH terms outside PubMed (Additional file 1). Follow up search strategies included hand searching relevant national websites including the Health Service Executive (HSE), Irish Prison Service (IPS), Departments of Health and Justice (DOH and DJ), the Irish Penal Reform Trust (IPRT), Health Surveillance Protection Centre (HSPC) and European Monitoring Centre for Drugs and Drug Addiction (EMCDDA). National experts and authors of existing papers were contacted to identify possible sources of unpublished and grey literature. Reference list were also manually searched by the team to identify relevant studies or literature not captured. References were managed by the citation manager Endnote $e^{\circ}$. This software facilitated the recording and organisation of all relevant literature and also allowed for the cross checking of data records, removal of duplicates and extraction of information from the papers included in the review. The literature search was completed in June 2018.

Eligibility criteria for study selection centred on whether studies broadly reported on any aspect of $\mathrm{HCV}$ infection in Irish PWUD or prisoners including those that reported findings from analysis of these groups within broader populations. Publications to be included were peer-reviewed research, published reports, guidelines and strategies, editorials, commentaries and audits. Articles were excluded if they did not report results on these specific cohorts. Researcher 1(DC) analysed all articles found by title to select those that were potentially relevant. The abstracts of all studies selected based on their titles were independently evaluated by researcher 2(RM) and any discrepancies were kept in the analysis.

Data was extracted and charted from all studies selected at the abstract stage, using an instrument designed for this study covering; date and author, setting, study population and sample size, data collection period, study design, $\mathrm{HCV}$ prevalence and associated risk factors, $\mathrm{HCV}$ incidence, treatment outcomes, barriers and facilitators to $\mathrm{HCV}$ care, knowledge and experience of living with $\mathrm{HCV}$, recommendations on the management of $\mathrm{HCV}$ and other outcomes. Data was extracted for each paper by a single researcher (DC) and checked by a second researcher (RM) to ensure that data extraction was accurate and comprehensive. The final decision to include studies was made based on this data extraction and whether it met the inclusion/exclusion criteria, based on independent evaluation by two authors (DC and RM), and a discussion of any discrepancies with the third author (TMcH).

A qualitative synthesis of the literature was carried out. The process of navigating and redefining the findings was iterative, and the researchers engaged with each stage in a reflexive manner, by fine tuning and repeating steps so as to ensure comprehensive synthesis of literature. Papers reporting on HCV incidence, prevalence, risk factors and screening uptake were categorised as epidemiological and reported and interpreted according to year of publication. For ease of reporting and interpretation this largest category was sub-categorised into those published in the last decade (2008-2018) and more historical studies published before 2008. The identified studies in this category reported on different populations (prisoners, PWID and PWUD on OST) and settings (prison, drug treatment centres and general practice).

The majority of the relevant literature retrieved from the web-site searches were either national reports, strategy documents or guidelines and were categorised as such. Studies reporting on outcomes following HCV diagnosis (self -clearance and sustained virologic response (SVR)) were categorised as treatment outcomes. The remaining literature was a mix of qualitative and quantitative studies that reported on a variety of outcomes including HCV -related health issues, alcohol consumption and patient and health provider experience of $\mathrm{HCV}$ infection and/or treatment and for convenience of reporting were categorised into $\mathrm{HCV}$-related health issues and patient and health- providers' experience. Where studies reported on a number of outcomes that crossed categories, these studies are categorised in the tables according to main/primary outcome and each outcome is reported in the result section according to its appropriate category. 


\section{Results}

Initial screening identified a total of 160 of which 27 were from grey literature and manual searching of reference lists. 117 met the inclusion criteria on title. Following a review of abstracts 42 studies were excluded. The remaining 75 studies were read in full and a further 17 were excluded. A total of 58 studies covering the period 19832018, were included in the final data synthesis (Fig. 1).

Five broad categories were identified to assist in the organisation of the literature. These were; Epidemiology, Guidelines and Policy, Treatment Outcomes, HCV -related Health Issues and qualitative research reporting on Patients' and Health Providers' Experiences.

\section{Epidemiology (32)}

For clarity the epidemiological studies have been grouped into studies reporting on HCV incidence and prevalence pre and post 2008. Within these time frames the studies are further categorised according to study population (prisoner, PWID and PWUD) and community location (drug treatment centre or primary care).
The findings from studies reporting on risk factors and HCV screening uptake along with identified gaps in surveillance data are reported at the end of this section.

\section{Pre-2008 (22 studies)}

Incidence (2 studies)

Two studies reported on HCV incidence in the pre-2008 period. The first was a 2003 a single-site study on HCV negative PWID attending methadone maintenance treatment (MMT) at the National Drug Treatment Centre (NDTC). Follow up screening on 100 patients found an HCV incidence of 66 (CI 51-84) per 100-person years (py). A larger 2005 study involving 21 drug treatment centre sites and 1459 PWUD reported an incidence of 24.5 per 100 py. [36, 37].

\section{Prevalence (20 studies) (prisoners $=3$ studies, PWUD $=7$} studies, $P W I D=8$ studies)

A total of papers was identified reporting on the prevalence of $\mathrm{HCV}$ infection in PWUD and prisoners in Ireland dating from 1983 to 2008.

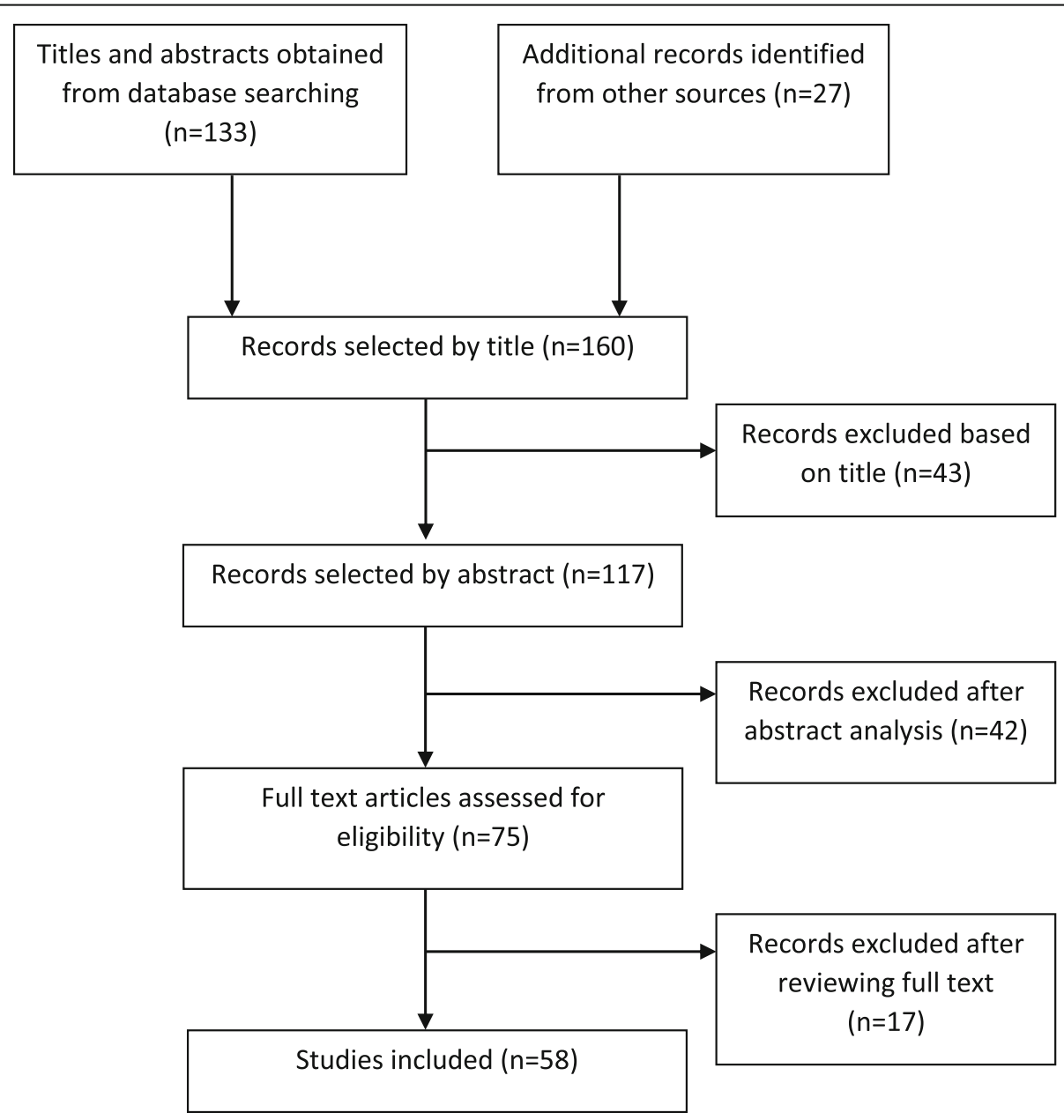

Fig. 1 Flow diagram 


\section{Prisoners}

Two studies were prison-based, one a randomised national study of the general prison population, the other was conducted on committal prisoners only. The 2000 study of 9/15 prisons in the Republic of Ireland (ROI) reported an anti- HCV prevalence of $37 \%$, increasing to $81 \%$ among those prisoners with a history of IDU. The 2001 multi-site committal study reported an anti- $\mathrm{HCV}$ prevalence of $3 \%$ in those who had never been imprisoned previously, $22 \%$ in prisoners aged $19-25$, increasing to $72 \%$ in prisoners with a history of IDU [38].

An interesting 2000 prison-based study reported on the discrepancy between self-reported HCV status and actual status (confirmed by oral swabs). Based on self-report the HCV prevalence estimates were 19\% but actual prevalence was double this rate (37\%) with small numbers $(5 \%)$ reporting being anti-HCV positive erroneously [16].

PWUD (Drug Treatment Centres $=4$ studies, Primary Care $=3$ studies $).$

Nine studies reported on HCV prevalence in PWUD attending MMT in community drug treatment clinics. The first was a 2001 multi-site randomised chart review of 715 patients attending MMT. This study reports an anti-HCV prevalence of $78.8 \%$ which reduced to $52 \%$ in those under 25 [39]. The 2005 incidence study described above reported an HCV prevalence of $66 \%$ in a population of PWUD attending drug treatment across 21 sites in the Dublin region [37]. A single site study from the NDTC reports an anti-HCV prevalence of $81.6 \%$ among study participants attending the centre for MMT during a 3-month period in 2002 [40]. A unique 2004 study reported an anti-HCV prevalence of $27 \%$ among adolescent drug users attending drug treatment, increasing to $55 \%$ among those with a history IDU [41].

A 2003 study involving 531 PWUD attending MMT at 42 general practice locations reported an anti-HCV prevalence of $78 \%$ [42]. A single site 2005 study reported an anti-HCV prevalence of $88 \%$ [43]. A later 2007 multisite study reported an anti-HCV prevalence of $69 \%$ [44].

PWID (Drug Treatment Centres $=7$ studies, Primary Care $=1$ study $)$.

A 1983 paper reported on the identification of non-A non-B exposure in $90 \%$ of a cohort of PWID with acute hepatitis undergoing biopsy at a single hospital site in Dublin [45].

Four studies were single site studies from the NDTC (1995-2000) three of which were on new entrants with varying lengths of IDU history. Among new entrants HCV prevalence ranged from 52 to $61.8 \%$ [17, 46, 47]. The single 1995 study reporting on $\mathrm{HCV}$ prevalence among PWID on methadone maintenance treatment (MMT) reported an anti-HCV prevalence of $84 \%$ [48].
A 2003 single-site study was the first to report on the prevalence of chronic HCV infection and genotype distribution in a PWID cohort. Of the 94 included in the prevalence part of this study, $74.5 \%$ were anti-HCV positive, $41.5 \%$ where HCV-RNA positive (chronic HCV infection). The genotype distribution was $66.6 \%$ genotype 1 and $25.6 \%$ genotype 3 . This study also included a mathematical modelling component to estimate national $\mathrm{HCV}$ burden levels [49]. These findings are reported in a later section of this review. A multi-site 2005 study involving 496 patient's mono-infected with $\mathrm{HCV}$ of whom 127 (with demonstrated self- clearance on initial testing) were followed up 2 years later. The initial testing showed a self-clearance of $38 \%$ which when followed up 2 years later had reduced to $31.1 \%$. The genotype distribution reported in this study was genotype $1=48.8 \%$ and genotype $3=48.5 \%$ [50]. A 2005 multi -site study (10 sites including 2 residential drug treatment sites) reported an anti-HCV prevalence of $61 \%$ among PWID who had a history of IDU in the past 6 months but who had never tested for HCV [51].

Only one single-site study reported specifically on $\mathrm{HCV}$ infection in PWID in primary care. This unique longitudinal study followed a cohort of 82 PWID attending a south inner-city Dublin general practice over 25 years. At the beginning of the study $\mathrm{HCV}$ infection had not been identified but at 10-year follow-up, 33\% of those still alive had been infected. At 25-year follow-up $40 \%$ of survivors were anti-HCV positive [52].

\section{At -risk population associated with PWUD (2 studies)}

Two studies reported on HCV prevalence in groups associated with PWUD. A single 2001 study reported that $82 \%$ of infants referred to an outpatient paediatric $\mathrm{HCV}$ clinic where from mothers with a history of IDU [53]. A 2008 study of homeless people found high levels of PWUD among this group (64\%) as well as a high prevalence of HCV exposure (36\%) [54] (Table 1).

\section{Post 2008 (10 studies)}

Incidence (1 study)

A 2016 study using mathematical modelling and data on 14, 320 PWID registered on the NDTRS estimated that 12,423 (CI 10,799-13,161) PWID were infected with HCV from 1991 to 2014, 9317 (CI 8022-9996) of whom had chronic infection. This paper also reported that new infections peaked in 1997, and that almost three quarters of those infected have the disease for greater than 10 years [19].

\section{Prevalence (9 studies) (Prisoner $=2$ studies, PWUD $=6$ studies, PWID = 1 study) \\ Prisoner}

A 2014 study conducted in 13/15 of the prisons in the ROI reported an anti-HCV prevalence of $13 \%$ (95\% CI 


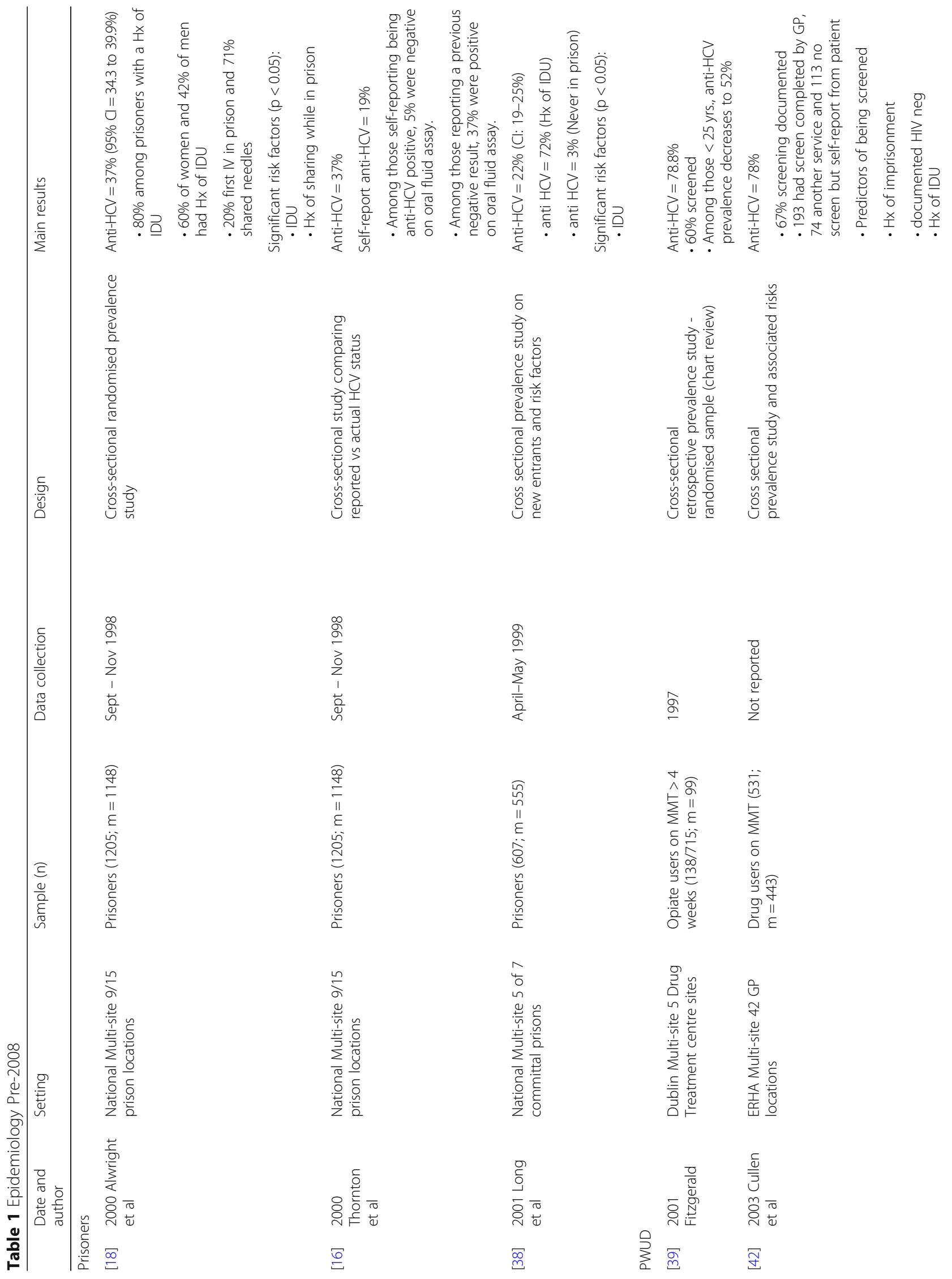




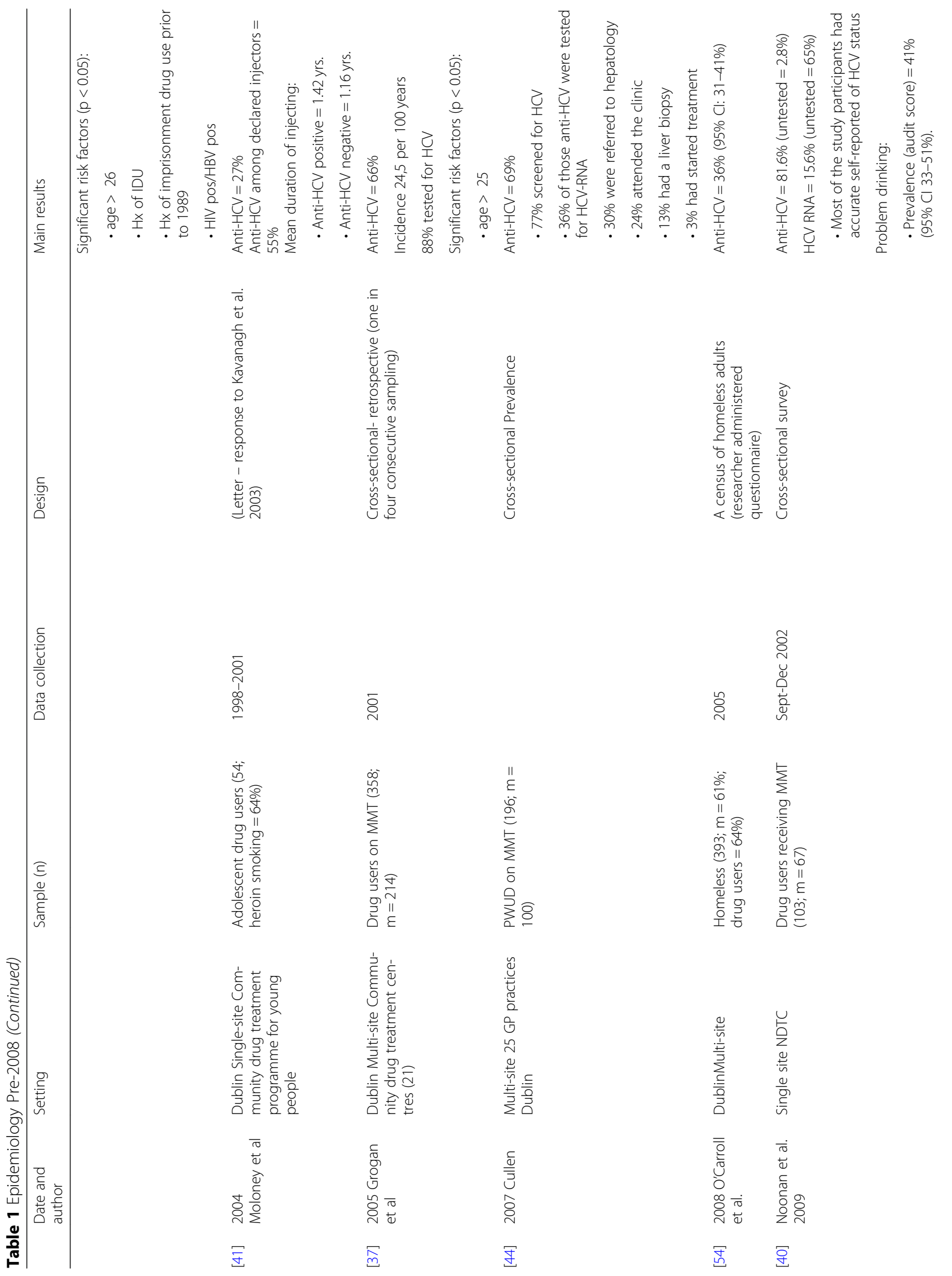




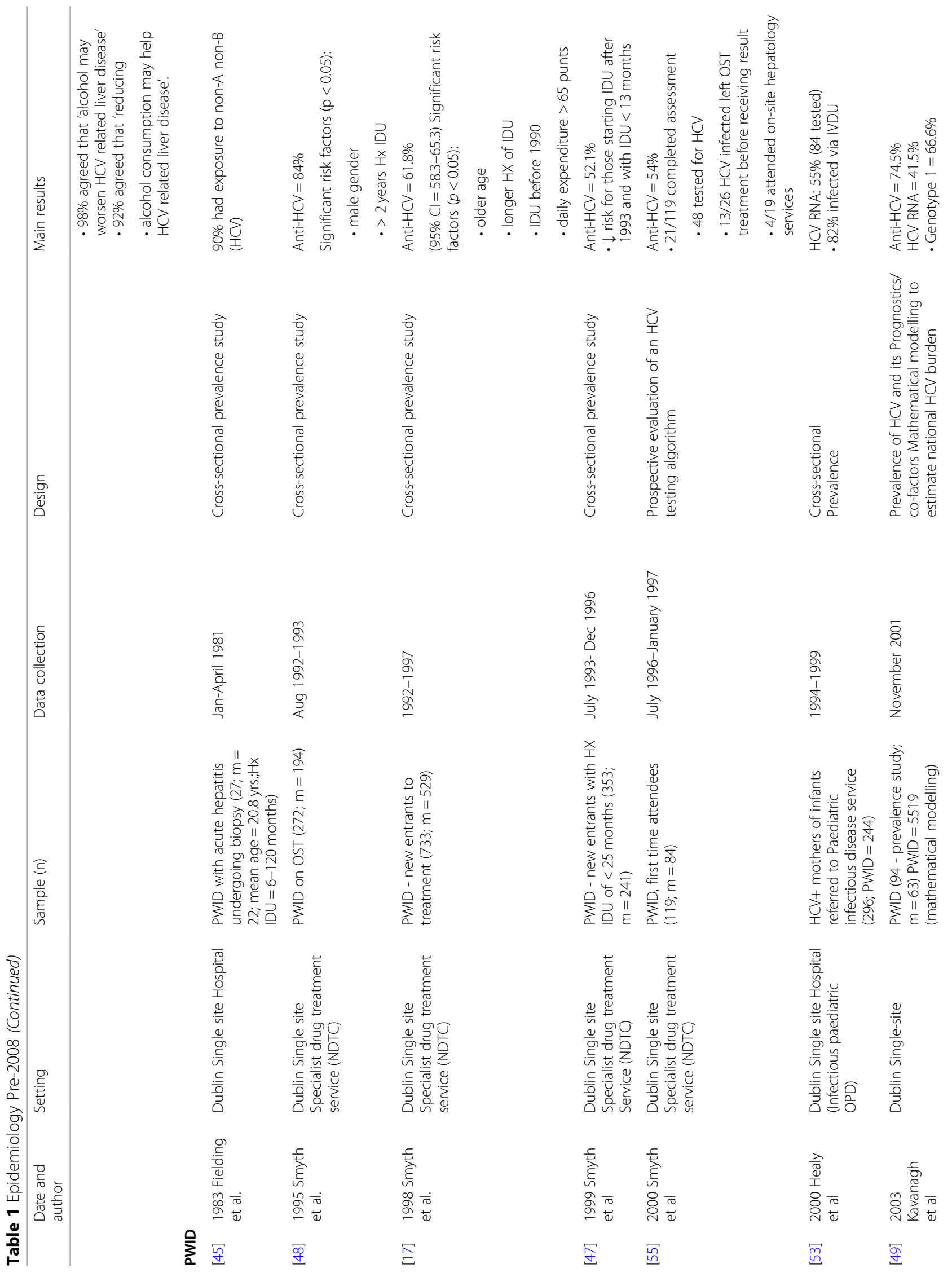









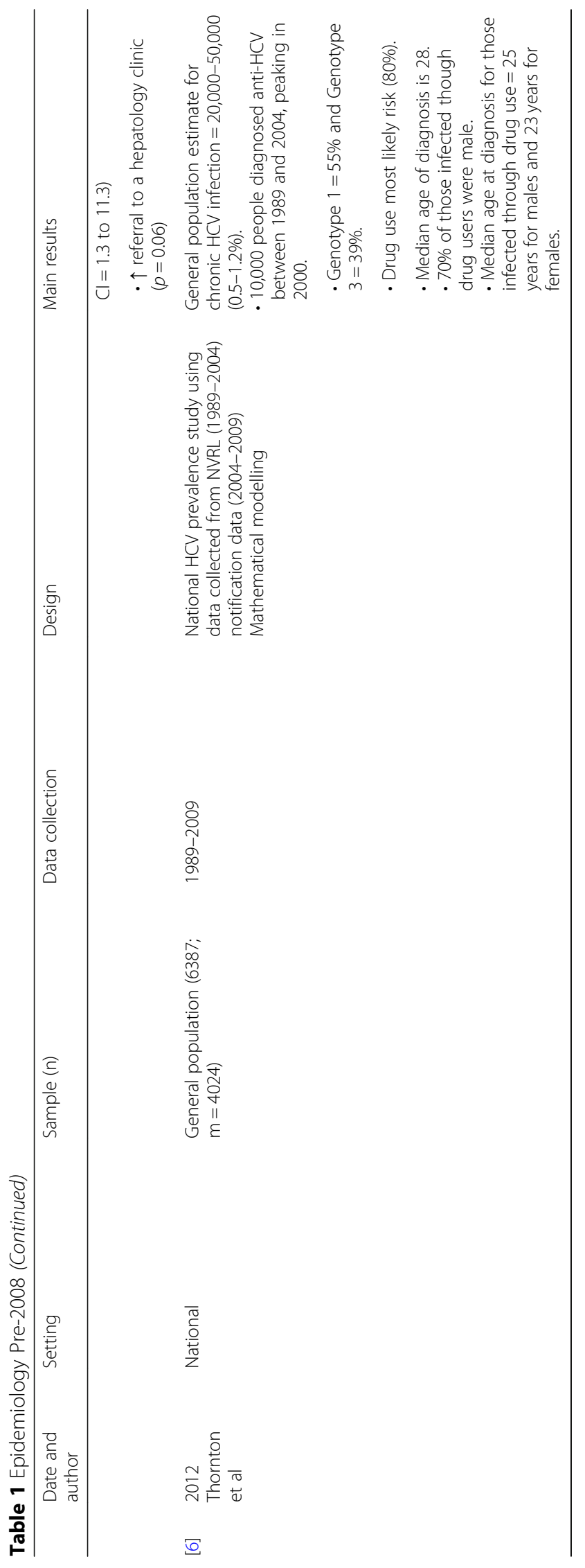


10.9-15.2\%) among the general prison population, increasing to $41.5 \%$ in prisoners with a history of IDU and $54 \%$ in those with a history of injecting heroin [13]. The most recent prison study from 2014 (single -site) reported an HCV prevalence of $37 \%$ among prisoners on MMT [57].

$P W U D$ (Drug Treatment Centres $=5$ studies, Primary Care $=1$ study $).$

Two 2014 studies identified from the grey literature reported on HCV infection in PWUD attending MMT in drug clinics outside of Dublin and reported an anti- HCV prevalence less than Dublin based studies (24\%\%) [58] (Horan A: Chart audit of HCV screening measuring the effect of chart labelling, unpublished). A published 2017 study reported an anti-HCV of $63.6 \%$ among PWUD attending MMT at a North Dublin inner city treatment centre [59]. Two recent large HCV screening audits, identified through the grey literature search, reported an anti-HCV prevalence of almost $80 \%$ and a chronic HCV prevalence of $65 \%$ among PWUD attending MMT at 23 drug treatment clinics in Dublin (Burke M: Audit of HCV screening using retrospective patient records, unpublished), (Burke M. Audit of $\mathrm{HCV}$ screening using retrospective patient records [Unpublished audit]). The most recent prevalence study in PWUD attending OST in general practice reported an anti-HCV prevalence of $77.2 \%$ among this group [60].

\section{PWID (1 study)}

A study conducted on PWID attending an inner-city accident and emergency department showed high levels of morbidity and HCV exposure (74\%) [61] (Table 2).

\section{HCV risk factors}

A total of 13 studies (1995-2017) reported on risk factors for $\mathrm{HCV}$ acquisition in both prisoner and PWUD populations. Prisoner risk factors identified were; a history of IDU, sharing needles while incarcerated, sharing drug taking equipment, older age, female gender, a previous history of incarceration and a history of having a prison tattoo. [13, 64, 65]. For drug users attending community-based OST risk factors identified were; a history of IDU, increased total number of lifetime injecting, closer social relationships with PWID, injecting in the homes of other PWID, a history of imprisonment, older age, male gender, drug use prior to 1989 , coinfected with HIV or HBV, younger age of first drug use, first IDU and entry to MMT and type of drug first used $[6,17,36,37,39,42,48,51,53,59]$.

\section{HCV screening uptake}

A number of the epidemiological studies reported on HCV screening uptake among the study population. The first was a 2001 multi-site randomised chart review of 715 patients attending MMT. This study reports a screening uptake of $60 \%$. The larger 2005 Dublin based multi-site study involving 1459 PWUD reported an 88\% uptake of HCV screening.

A single site study from the NDTC reports very high levels of HCV screening uptake and an anti-HCV prevalence of $81.6 \%$ among study participants [40]. However only a third of anti-HCV patients were RNA tested showing a chronic HCV prevalence of $15.6 \%$. This study also found high levels of accuracy for HCV self-report [40].

A 2003 study involving 531drug users attending MMT at 42 general practice locations reported that over two thirds had an HCV screen [42]. Two large HCV screening audits, identified through the grey literature search, reported high levels of HCV screening (Burke M: Audit of $\mathrm{HCV}$ screening using retrospective patient records, unpublished),(Burke M. Audit of HCV screening using retrospective patient records [Unpublished audit]). Dublin. Uptake of HCV screening was less than in Dublin clinics (50\%) (Horan, 2014; Ryan \& Ryan, 2014) The Cork (second largest city in Ireland) study identified that chart labelling (starring) had a positive impact on the uptake of screening among this patient cohort (Horan A: Chart audit of HCV screening measuring the effect of chart labelling, unpublished). The most recent prevalence study in PWUD attending OST in general practice reported high uptake of HCV screening (92.5\%) [60]. A later 2007 multi-site study reported high levels of HCV screening among PWUD on MMT in Dublin based general practice (77\%) [44]. Only a third of those infected had been screened for chronic infection (36\%) [44].

\section{Identified gaps}

No studies reported on incidence infections specifically in prisoners, PWUD or PWID in general practice or not on OST and PWUD without a history of IDU. Only two studies reported on HCV prevalence in PWUD outside of Dublin and both where from secondary urban centres. The majority of the prevalence studies are over a decade old and only report on anti-HCV prevalence and not on HCV-RNA prevalence which limits their usefulness at estimating the levels of chronic untreated infection and reinfection. The most recent epidemiological studies included in this review are mostly chart review audits which limit their usefulness to inform policy and strategy.

\section{Guidelines and policy (8 studies)}

A total of 8 documents were identified that fitted into this category. The first published national document relating to $\mathrm{HCV}$ infection in PWUD and prisoners was published in 2004 [66]. This was a regional (Dublinbased) document that reported on the views of 70 stakeholders (service planners, funders, providers and users) 


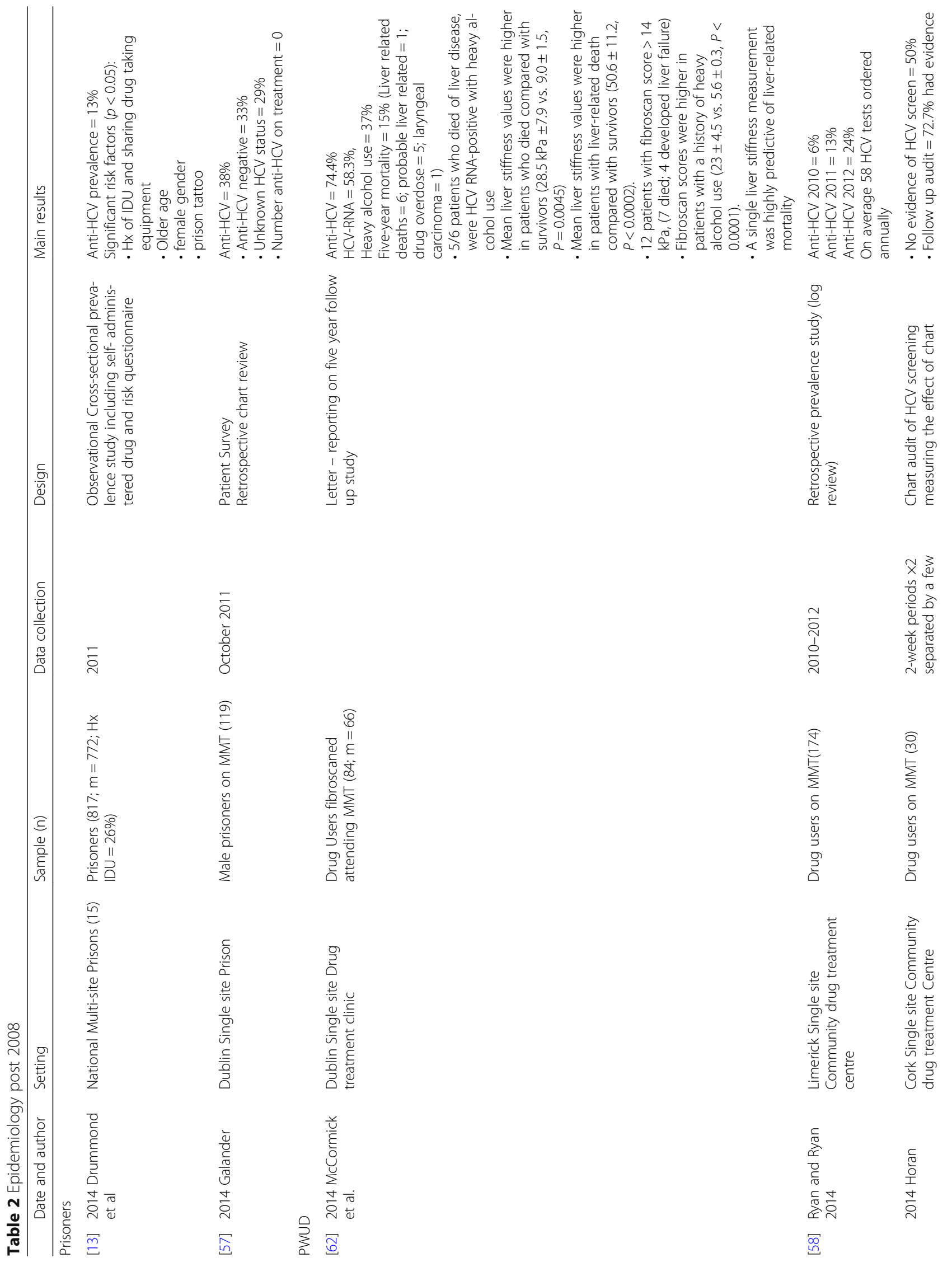




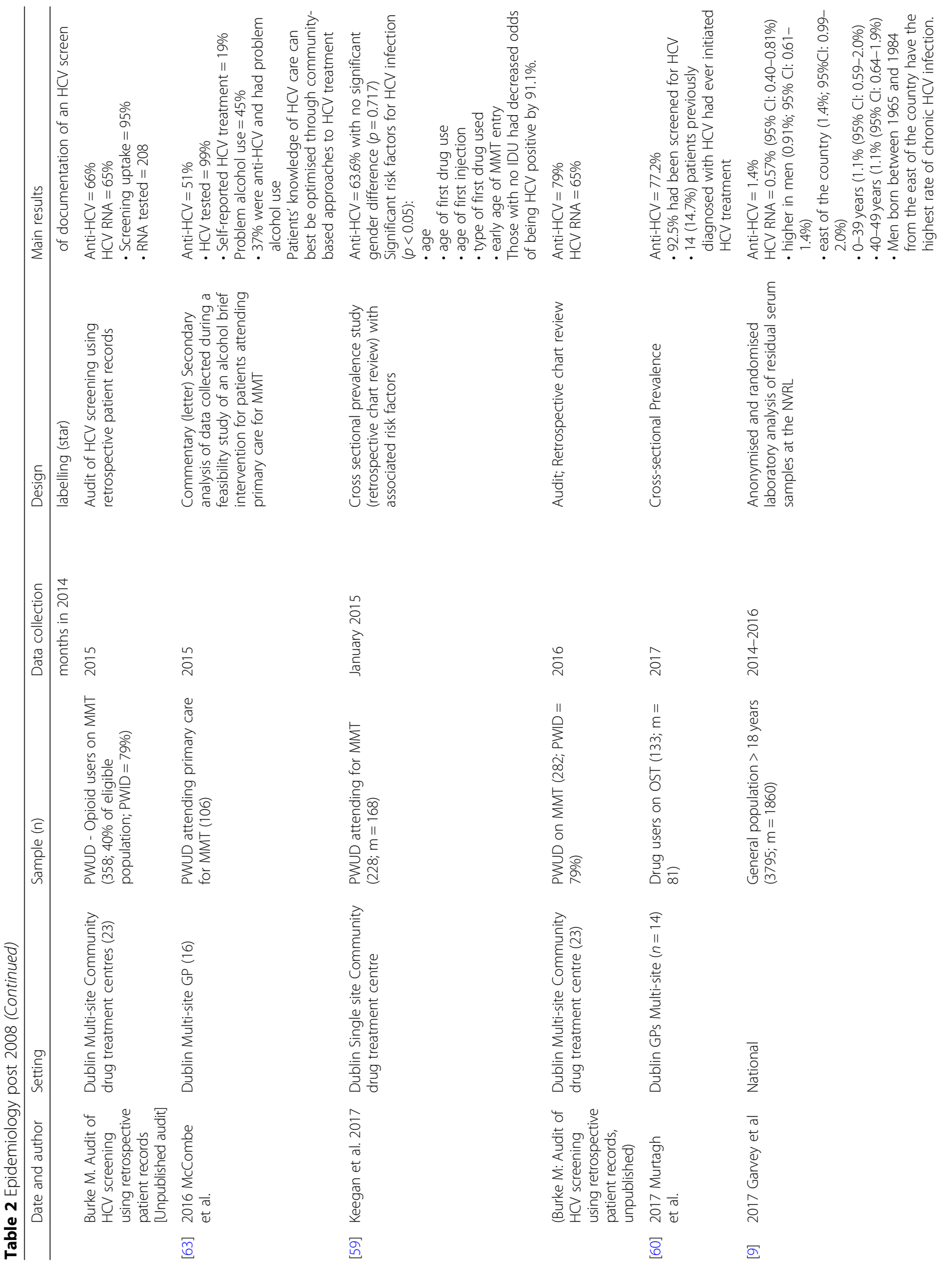




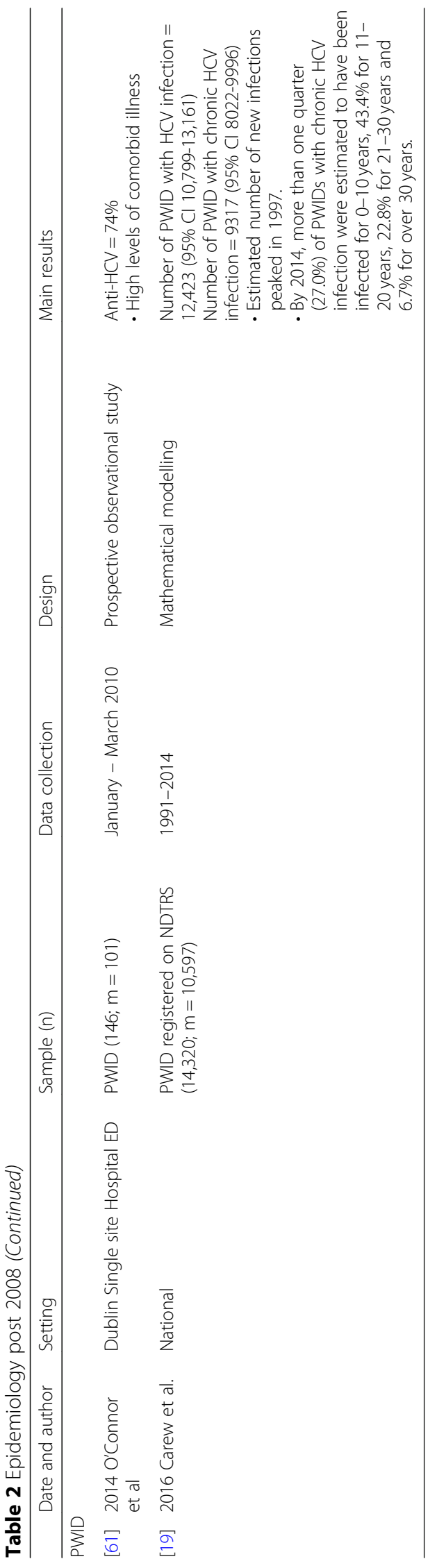


on a broad range of HCV related issues including policy and clinical issues [66].

In the same year, a research lead initiative developed consensus guidelines on $\mathrm{HCV}$ management in general practice [67]. The effectiveness of these guidelines was later evaluated in a cluster randomised trial and were found to improve the uptake of screening in practices where the policy was implemented $(\mathrm{OR}=3.76 \mathrm{CI}=$ 1.3-11.3) [56].

The National Hepatitis C Strategy 2011-2014 was the first published strategy relating to all those infected with HCV in Ireland [14]. The strategy spans surveillance, prevention, screening and treatment of $\mathrm{HCV}$ infection and reports on both groups (PWUD and prisoners). The Department of Health (DOH) subsequently published a report: A Public Health Plan for the Therapeutic Treatment of Hepatitis $C$ in 2015 which recommended the establishment of the National Hepatitis C Treatment Programme (NHCTP) in the HSE [68].

The NHCTP was established in 2014 and oversees treatment provision to all $\mathrm{HCV}$ infected patients in Ireland, including PWUD and prisoners [26]. This program has a number of specialist committees that advise on the treatment criteria and guidelines and also includes a treatment register which collects data on treatment uptake and outcomes.

The HSE developed national HCV screening guidelines to identify $\mathrm{HCV}$-infected individuals who are currently unaware of their HCV status [10]. These guidelines were preceded by two opioid substitution guidelines that contained recommendations on the screening of drug users on OST [69].

The Irish Prison Services are responsible for the provision of health care in all prisons in the ROI and in parallel to community-based guidelines have further sets of guidelines that deal specifically with $\mathrm{HCV}$ management within the IPS [70]. The provision of all healthcare, including $\mathrm{HCV}$ treatment is guided by the international principle of community equivalence of care [71].

The major gap identified in this category is that the national strategy was published pre-DAA and no longer reflects the reality of $\mathrm{HCV}$ treatment in particular the challenges related to moving HCV treatment from hospital services to the community. The new national HCV screening guidelines provides a clear road map on who to screen but to date there is not data on the success of their implementation. It is also important that the IPS update their health care standards in line with the new national screening guidelines and NHCTP to ensure community equivalence (Table 3 ).

\section{Treatment outcomes (13 studies)}

A number of papers reported on treatment uptake and outcomes. These studies found poor engagement with hepatology services for liver assessment and treatment by PWUD [43, 44, 55, 60, 63, 73]. Predictors for poor treatment follow up were, younger age, active IDU and advanced HIV disease, male gender $[74,75]$. A single prison study reported that no $\mathrm{HCV}$ infected prisoner on MMT was on HCV treatment at the time of the study [57].

A number of studies reported SVR from interferon -based treatment and found SVR ranging from (5374\%) with PWID having similar outcomes to other patients [74-77].

In-reach hepatology services provided HCV treatment at two Dublin based prison location. An audit of these sites shows high compliance with treatment and good treatment outcomes [78].

A single study reported on the use of tele-medicine as a novel approach to increasing treatment among $\mathrm{HCV}$ infected PWUD attending MMT. This study showed high levels of satisfaction among professionals engaging with the initiative [79].

A number of gaps in the treatment outcome literature were identified including: the lack of SVR outcomes for DAA treatment, re-infection rates and treatment uptake and completion rates. There are no mathematical modelling studies conducted using existing surveillance data and treatment uptake and outcomes to map pathways towards HCV elimination in Ireland (Table 4).

\section{HCV -related health issues (8 studies)}

A number of studies reported on HCV related health issues. Two hospital-based studies found higher levels of depression and anxiety among $\mathrm{HCV}$ infected patients whose risk factor for acquisition was IDU [80, 81].

A 2003 mathematical modelling study estimating the national $\mathrm{HCV}$ - related disease burden over 20 years, predicted 1214 cases of cirrhosis, 35 cases of HCC, 60 cases of hepatic decompensation and 50 cases of liver related deaths per annum [49].

A number of papers describe high levels of alcohol use among HCV infected PWUD (41\%) [40, 62, 63]. Studies report high levels of $\mathrm{HCV}$-related liver disease and awareness that excessive alcohol had a negative impact on $\mathrm{HCV}$ disease progression among PWUD on OST [62, 73] [40].

A 25 year follow up study of PWID attending general practice found high levels of mortality in a cohort with $\mathrm{HCV}$ exposure having a negative impact on life expectancy (O'Kelly \& O'Kelly, 2012). A unique five-year follow up study among PWUD attending OST showed high mortality rates of among patients with high Fibroscan scores which was associated with heavy alcohol use. The study concluded that a single Fibroscan score was highly predictive of mortality (McCormick et al., 2014). 
Table 3 Guidelines and policy

\begin{tabular}{|c|c|c|c|c|c|c|}
\hline & Date and author & Setting & Sample (n) & $\begin{array}{l}\text { Data } \\
\text { collection }\end{array}$ & Design & Main results \\
\hline$\overline{[67]}$ & $\begin{array}{l}2004 \text { Dublin Area Hepatitis } \\
\text { C Initiative Group }\end{array}$ & ERHA & GPS & $2001-2002$ & $\begin{array}{l}\text { Descriptive study reporting on } \\
\text { HCV management guideline } \\
\text { development for GPs }\end{array}$ & $\begin{array}{l}\text { The guidelines cover advice to GPS } \\
\text { on all aspects of care of patients at } \\
\text { risk of HCV, including } \\
\text { - general and preventative care } \\
\text { - care of other bloodborne and } \\
\text { hepatotoxic viruses } \\
\text { - factors to be considered and } \\
\text { appropriate evaluation prior to } \\
\text { referring a patient for assessment } \\
\text { at a hepatology unit. }\end{array}$ \\
\hline$[66]$ & $\begin{array}{l}2004 \\
\text { Hepatitis C Scientific } \\
\text { Advisory Subgroup of the } \\
\text { Blood Borne Virus Forum } \\
\text { and the Eastern Regional } \\
\text { Health Authority }\end{array}$ & ERHA & $\begin{array}{l}16 \text { workshops with service } \\
\text { planners, health and social } \\
\text { care professionals and } \\
\text { service users ( } 70\end{array}$ & 2004 & $\begin{array}{l}\text { A regional hepatitis } C \text { strategy } \\
\text { document using open space } \\
\text { technology }\end{array}$ & $\begin{array}{l}\text { Reported on: } \\
\text { - health promotion } \\
\text { - role of the media } \\
\text { - service provision } \\
\text { - research, policy and planning } \\
\text { - education and training, } \\
\text { - liaison } \\
\text { - key workers } \\
\text { - co-ordination and collaboration } \\
\text { - accessing services } \\
\text { - psychological and } \\
\text { complementary therapies }\end{array}$ \\
\hline [72] & 2006 Long & National & Drug users & 1995-2005 & Review & $\begin{array}{l}\text { Reports on } \\
.9 \text { prevalence studies } \\
.7 \text { studies identifying risk factors }\end{array}$ \\
\hline [70] & 2009 IPS & Dublin & Prisoners & - & Guidelines & $\begin{array}{l}\text { Provide prisoners } \\
\text { - general health information } \\
\text { - advice and testing } \\
\text { - referral to appropriate specialist } \\
\text { services in relation to HCV where } \\
\text { clinically indicated } \\
\text { - treatment and support for those } \\
\text { chronically infected. }\end{array}$ \\
\hline [14] & 2012 HSE & National & PWID \& prisoners & 2007 & First national strategy & $\begin{array}{l}\text { - Reviewed and updated } \\
\text { recommendation from the } 2004 \\
\text { ERHA report. } \\
\text { - Developed 36-point action plan } \\
\text { Prioritising recommendations for } \\
2011-2012 \text { in the areas of HCV } \\
\text { surveillance, education, preven- } \\
\text { tion and treatment. }\end{array}$ \\
\hline [68] & $2014 \mathrm{DOH}$ & National & HCV infected patients & - & Guidelines & $\begin{array}{l}\text { Recommendations: } \\
\text { - HSE establish a Hepatitis C } \\
\text { Treatment Programme with a } \\
\text { strong governance and } \\
\text { management structure } \\
\text { - Provide drug treatment to those } \\
\text { with greatest clinical need as a } \\
\text { priority and treat as many } \\
\text { patients as possible with the } \\
\text { available resources }\end{array}$ \\
\hline [69] & HSE 2017 & National & & & OST Guidelines & $\begin{array}{l}\text { - All drug users (including non- } \\
\text { PWID) should be screened for } \\
\text { HCV. } \\
\text { - Anti-HCV patients should be } \\
\text { tested for HCV-antigen and LFTs } \\
\text { - all antigen positive patients } \\
\text { should be referred to specialist } \\
\text { services for PCR, fibroscanning } \\
\text { and consideration for treatment. } \\
\text { - All patients at risk of HCV } \\
\text { infection should be given } \\
\text { information and advice on the } \\
\text { disease and how it is transmitted. } \\
\text { - IDU and alcohol misuse should } \\
\text { not exclude patients from } \\
\text { treatment. } \\
\text { - Risks of concurrent alcohol use } \\
\text { should be explained to anti-HCV } \\
\text { patients. }\end{array}$ \\
\hline
\end{tabular}


Table 4 Treatment outcomes (7 studies)

\begin{tabular}{|c|c|c|c|c|c|c|}
\hline & Date and author & Setting & Sample (n) & Data collection & Design & Main results \\
\hline [50] & 2005 Keating et al & $\begin{array}{l}\text { Dublin Multi-site } 5 \\
\text { drug treatment } \\
\text { centres }\end{array}$ & $\begin{array}{l}\text { PWID mono-infected } \\
\text { with HCV }(496 ; m=341 \\
2 \text { years follow up }=127)\end{array}$ & $\begin{array}{l}\text { Jan 1997- Nov } \\
2001 \text { Repeat } \\
\text { follow up testing } \\
\text { in } 2003\end{array}$ & $\begin{array}{l}\text { Cross-sectional } \\
\text { prospective study on } \\
\text { HCV clearance }\end{array}$ & $\begin{array}{l}\text { HCV RNA: } \\
\text { - Negative = 38\% (self- } \\
\text { clearance) }(f=47.4 \% ; m= \\
34.5 \%) \\
\text { - Follow up ( } 2 \text { yrs) }=82.2 \% \\
\text { sustained viral clearance } \\
\text { - Overall viral clearance = } \\
31.1 \% \\
\text { - Genotype distribution } \\
(1=48.8 \% ; 3=48.5 \%)\end{array}$ \\
\hline$[76]$ & 2006 Hopkins & Single site Hospital & $\begin{array}{l}\text { Co-infected with HIV } \\
\text { and HCV patients with } \\
\text { CD4 counts }>200 \text { cells/ } \\
\mathrm{mL} \\
(45 ; \mathrm{m}=39 ; \mathrm{PWID}=58 \%)\end{array}$ & June 2001-2003 & $\begin{array}{l}\text { Open-label, } \\
\text { prospective study }\end{array}$ & $\begin{array}{l}\text { SVR }=53 \% \\
\text { - Genotype } 2 \text { and } 3 \\
\text { patients had a significantly } \\
\text { higher SVR ( } 75 \%) \text { than } \\
\text { genotype } 1(19 \%) \\
\text { - Adverse events occurred } \\
\text { frequently }\end{array}$ \\
\hline [74] & 2011 Kieran et al & $\begin{array}{l}\text { Dublin Single-site } \\
\text { Hospital Integrated } \\
\text { HIV/HCV clinic }\end{array}$ & $\begin{array}{l}\text { Co-infected attendees } \\
(386 ; \mathrm{m}=278)\end{array}$ & $\begin{array}{l}\text { October 2008- } \\
\text { January } 2009\end{array}$ & $\begin{array}{l}\text { Retrospective chart } \\
\text { review }\end{array}$ & $\begin{array}{l}\text { 202/386 - referred to co- } \\
\text { infected clinic, with } 107 \\
\text { completing treatment } \\
\text { - SVR }=44 \% \text { (similar } \\
\text { outcomes for PWID } \\
\text { compared to patients } \\
\text { with other transmission } \\
\text { risks) } \\
\text { Associations with missed } \\
\text { appointments } \\
\text { - younger age } \\
\text { - active IDU } \\
\text { - advanced HIV infection } \\
\text { Dedicated co-infection } \\
\text { clinics lower the threshold } \\
\text { for treatment and improve } \\
\text { management of liver dis- } \\
\text { ease in co-infected patients }\end{array}$ \\
\hline$[75]$ & 2011 Lowry et al & $\begin{array}{l}\text { Dublin Single-site } \\
\text { Hospital }\end{array}$ & $\begin{array}{l}\text { HCV mono-infected pa- } \\
\text { tients referred ( } 588 \text { indi- } \\
\text { viduals (repeat } \\
\text { referrals }=742 \text { cases); } \\
\mathrm{m}=388 \text {; PWID }=74 \% \text { ) }\end{array}$ & $2000-2007$ & $\begin{array}{l}\text { Retrospective chart } \\
\text { review }\end{array}$ & $\begin{array}{l}\text { SVR }=74 \% \\
\text { - History of IDU was not a } \\
\text { significant predictor of } \\
\text { lower therapy completion } \\
\text { rate or achievement of } \\
\text { SVR } \\
\text { In total, } 451 \text { (61\%) dropouts } \\
\text { occurred } \\
\text { - } 141 \text { (19\%) failed to attend } \\
\text { their initial appointment } \\
\text { - } 180 \text { dropped out from } \\
\text { early outpatient } \\
\text { management } \\
\text { - } 29 \text { failed to attend liver } \\
\text { biopsy } \\
\text { - } 81 \text { defected from } \\
\text { subsequent outpatient } \\
\text { follow-up. } \\
\text { Statistically significant } \\
\text { associations with history of } \\
\text { injection drug use } \\
\text { - dropout immediately after } \\
\text { the referral ( } P<0.001) \\
\text { - dropout from early } \\
\text { outpatient management } \\
\text { (P<0.001) } \\
\text { - dropout over entire span } \\
\text { of disease management } \\
(P<0.001) \\
\text { Male sex was also } \\
\text { associated with dropout } \\
\text { from disease management }\end{array}$ \\
\hline
\end{tabular}


Table 4 Treatment outcomes (7 studies) (Continued)

\begin{tabular}{|c|c|c|c|c|c|c|}
\hline & Date and author & Setting & Sample (n) & Data collection & Design & Main results \\
\hline & & & & & & $(P<0.05)$ \\
\hline [52] & $\begin{array}{l}2012 \text { Kelly and } \\
\text { Kelly }\end{array}$ & Dublin Single site GP & PWID $(82 ; m=62 \%)$ & $1985-2010$ & $\begin{array}{l}\text { Longitudinal cohort } \\
\text { study }\end{array}$ & $\begin{array}{l}\text { Anti-HCV }=33 \% \text { at } 10 \text { yrs. } \\
\text { (survivors) } \\
\text { Anti-HCV }=40 \% \text { at } 25 \text { yrs. } \\
\text { (survivors) } \\
\text { - } 63 \% \text { of the cohort had } \\
\text { died by } 2010 \text {, of which } 26 \\
\text { were attributed to HIV } \\
\text { disease } \\
\text { - Median survival time for } \\
\text { those ant-HCV }=21 \text { years } \\
\text { ( } 95 \% \mathrm{Cl} 15.5-26.5 \text { ) which } \\
\text { was significantly lower } \\
\text { than the median survival } \\
\text { time for drug users with a } \\
\text { negative hepatitis } C \text { status. } \\
\text { ( } p=0.006 \text { ) }\end{array}$ \\
\hline$[77]$ & 2017 Elsherif et al & $\begin{array}{l}\text { Dublin Single-site } \\
\text { Hospital }\end{array}$ & $\begin{array}{l}\text { HCV infected patients } \\
\text { (1000; Former PWID (>6 } \\
\text { months) = 608; Recent } \\
\text { PWID (<6 months) }=85 \\
\text { Non-drug users }=307 \text { ) }\end{array}$ & 2002-2012 & $\begin{array}{l}\text { Retrospective chart } \\
\text { review }\end{array}$ & $\begin{array}{l}\text { SVR in PWID }=64.2 \% \\
\text { - No significant compared } \\
\text { to non-PWID }(60.9 \%)[R R= \\
1.05,95 \% \text { Cl } 0.95 \pm 1.17] \\
\text { - There was no significant } \\
\text { difference in SVR rates } \\
\text { between the groups } \\
\text { controlling for genotype } \\
\text { (48.4\% vs } 48.4 \% \text { for } \\
\text { genotype } 1 ; 74.9 \text { vs } 73.3 \% \\
\text { for genotype } 3) \text {. } \\
\text { - No significant difference } \\
\text { in treatment non- } \\
\text { adherence between the } \\
\text { groups (8.4\% in PWID vs } \\
6.8 \% \text { in non-PWIDs; RR = } \\
1.23, \text { Cl } 0.76 \pm 1.99) \\
\text { - Former and recent PWID } \\
\text { had similar adherence } \\
\text { rates. }\end{array}$ \\
\hline
\end{tabular}

Overall the research on $\mathrm{HCV}$ related health issues was considered to be scant and incomplete. While a number of studies report on levels of liver disease in small groups of PWUD on OST, the literature does not provide a clear picture of the HCV disease burden in these two groups. In the early days of DAA treatment $\mathrm{HCV}$ infected patients with advanced liver disease were prioritised for treatment access but it is unclear how many of these accessed or completed treatment. There is also no published data on the numbers of HCV infected PWUD who die annually from non-HCV related causes. This may be considerable given the high levels of drug related deaths in Ireland and if not accurately quantified will have an impact on Irish $\mathrm{HCV}$ elimination strategies (Table 5).

\section{Qualitative research reporting on patients' and health providers' experiences}

A number of studies report a high awareness of HCV infection among PWUD on OST both in primary care and drug treatment centres [40, 43]. This includes the knowledge that IDU is a major risk factor for transmission among this group and the health implications of being infected [43]. There were also high levels of awareness of patients own HCV status, of HCV harm reduction measures, and adverse effects alcohol has on the progression of $\mathrm{HCV}$ liver disease $[40,43]$.

A prison-based study exploring the health needs of female prisoners using focus group methodology reported that $\mathrm{HCV}$ infection was identified as a health concern among Irish female prisoners [25].

A single study reported on negative patient experiences with regard to testing, assessment and treatment [43]. HCV related stigma was reported in many of the qualitative studies [25, 43, 73, 81-84].

A number of studies identified barriers to PWUD engagement in $\mathrm{HCV}$ treatment including; ongoing alcohol and drug use, fear of HCV treatment and liver biopsy, imprisonment, distance to hospital, early morning appointments, perceptions of $\mathrm{HCV}$ infection as relatively benign, fear of investigations and treatment including liver biopsy and interferon, feeling well, limited knowledge of testing sites, not being referred for specialist 
Table 5 HCV-related health issues

\begin{tabular}{|c|c|c|c|c|c|c|}
\hline & Date and author & Setting & Sample (n) & $\begin{array}{l}\text { Data } \\
\text { collection }\end{array}$ & Design & Main results \\
\hline [80] & 2001 Goulding et al & $\begin{array}{l}\text { Dublin Single-site } \\
\text { Hospital }\end{array}$ & $\begin{array}{l}\text { Patients with chronic } \\
\text { HCV infection }(77 ; \mathrm{m}= \\
17 ; \mathrm{PWID}=25)\end{array}$ & & $\begin{array}{l}\text { Cross-sectional } \\
\text { Prevalence of } \\
\text { rheumatological disease, } \\
\text { anxiety and depression } \\
\text { and relationship to } \\
\text { mode of acquisition }\end{array}$ & $\begin{array}{l}\text { Anxiety and depression scores } \\
\text { were significantly higher in } \\
\text { IVDUs }(P=0.005) \text { compared } \\
\text { with controls. }\end{array}$ \\
\hline$[82]$ & 2005 Golden et al & $\begin{array}{l}\text { Dublin Single-site } \\
\text { Hospital }\end{array}$ & $\begin{array}{l}\text { HCV infected patients } \\
\text { awaiting interferon } \\
\text { treatment }(90 ; m=67 ; \\
47 \% \text { PWID) }\end{array}$ & & $\begin{array}{l}\text { Prevalence of mood } \\
\text { disorder and associated } \\
\text { risks using a self- } \\
\text { completed structured } \\
\text { questionnaire }\end{array}$ & $\begin{array}{l}\text { Depressive disorders: } \\
\text { - } 1 \text {-month prevalence = } 21 \% \\
\text { ( } 72 \% \text { previously } \\
\text { undiagnosed) } \\
\text { - Current MMT strongly } \\
\text { associated with risk of } \\
\text { depression (OR, 5.0; } 95 \% \mathrm{Cl} \text {, } \\
\text { 1.08-23.0). } \\
\text { - After adjustment for age and } \\
\text { sex, depression was } \\
\text { associated with poorer work } \\
\text { and social adjustment, lower } \\
\text { acceptance of illness, higher } \\
\text { illness stigma, poorer } \\
\text { reported thinking and } \\
\text { concentration, and higher } \\
\text { levels of subjective physical } \\
\text { symptoms (all P<.05) } \\
\text { Anxiety disorders: } \\
\text { - 1-month prevalence = 24\% } \\
\text { (86\% previously } \\
\text { undiagnosed) } \\
\text { - Anxiety disorders were } \\
\text { uncorrelated with any risk } \\
\text { factor. }\end{array}$ \\
\hline [78] & 2018 Mc Kiernan et al & $\begin{array}{l}\text { Prisons Multi-site } \\
\text { Community Single } \\
\text { site (hospital) }\end{array}$ & $\begin{array}{l}\text { HCV infected prisoners } \\
\text { referred for HCV } \\
\text { treatment }(510 ; \\
\text { Treatment outcomes = } \\
\text { 104) }\end{array}$ & 2010-2018 & $\begin{array}{l}\text { Retrospective record } \\
\text { audit Comparisons } \\
\text { between community } \\
\text { and prison populations }\end{array}$ & $\begin{array}{l}\text { SVR prison }=90.3 \% \text { SVR } \\
\text { community }=87.5 \% \text { Referrals: } \\
\text { - Mountjoy }=265 \\
\text { - Wheatfield }=173 \\
\text { - Midlands }=33 \\
\text { - Portlaois }=15 \\
\text { - Limerick }=6 \\
\text { - Others }=11\end{array}$ \\
\hline
\end{tabular}

investigations, ineligibility for treatment and competing priorities (employment, education, and addiction) [43, $73,79,83]$. Some of these studies reported on enablers to PWUD engagement which included; afternoon appointments, enhanced prison referral mechanisms into the community, community fibroscanning, location of services within the addiction treatment services, relationships with health care providers, trust in providers, concern for the service-user, continuity of care, education on $\mathrm{HCV}$ infection, investigations, and treatment, becoming symptomatic, responsibilities for children, wanting to move on from drug use [73, 83].

Only two studies reported on healthcare professionals' experience of providing care to $\mathrm{HCV}$ infected prisoners and PWUD. A single prison study reported lack of knowledge regarding BBVs including $\mathrm{HCV}$ had a negative impact on prison officers' work [85]. A recent study identified lack of time and inadequate funding as barriers to community GPs engaging with HCV treatment [79].
As previously identified the major deficit in this category is that it reports from a pre-DAA era. This is particularly relevant for barriers to treatment engagement which was related to the fear and experience of side effects of interferon- based treatments. There is a need to conduct more up to date quantitative research on PWUD $S^{\prime}$ and prisoners' experience of the HCV treatment cascade with DAA treatments. This can best inform the planning of effective $\mathrm{HCV}$ delivery systems (Table 6).

\section{Discussion}

Overall this review found a larger than expected quantity and greater scope of literature published on $\mathrm{HCV}$ infection in Irish prisoners and PWUD. The literature was both quantitative and qualitative, employed many different methodologies and covered a 35-year period from 1983 to 2018. 
Table 6 Qualitative research reporting on patients' and health providers' experiences

\begin{tabular}{|c|c|c|c|c|c|c|}
\hline & $\begin{array}{l}\text { Date and } \\
\text { author }\end{array}$ & Setting & Sample (n) & Data collection & Design & Main results \\
\hline [43] & $\begin{array}{l}2005 \text { Cullen } \\
\text { et al }\end{array}$ & $\begin{array}{l}\text { Dublin Single site } \\
\text { General practice }\end{array}$ & $\begin{array}{l}\text { Heroin users - past } \\
\text { history (25) }\end{array}$ & 2002 (6 months) & $\begin{array}{l}\text { Mixed methods using } \\
\text { interviewer-administered } \\
\text { semi-structured } \\
\text { questionnaire }\end{array}$ & $\begin{array}{l}\text { Anti-HCV }=88 \% \\
\text { - Follow up investigations for } \\
\text { HCV }=8 \\
\text { - Treatment }=1 \\
\text { - } 100 \% \text { aware of HCV } \\
\text { - } 22 / 25 \text { consulted healthcare } \\
\text { professional about HCV } \\
\text { - } 21 / 25 \text { knew HCV infection } \\
\text { was caused by injecting } \\
\text { - High awareness of harm } \\
\text { reduction measures and } \\
\text { health implications of HCV } \\
\text { - Negative experiences of } \\
\text { diagnosis, assessment and } \\
\text { treatment }\end{array}$ \\
\hline [85] & 2005 Dillon & $\begin{array}{l}\text { Dublin Multi-site } 4 \\
\text { prisons }\end{array}$ & Prison officers & & Cross sectional survey & $\begin{array}{l}\text { - } 87 \% \text { reported not knowing } \\
\text { enough about these diseases } \\
\text { to enable them to take the } \\
\text { necessary precautions at } \\
\text { work } \\
\text { - Longer serving and senior } \\
\text { officers were less fearful and } \\
\text { less anxious about } \\
\text { contracting the infections } \\
\text { - Officers who had received } \\
\text { hepatitis B vaccination were } \\
\text { no less worried about } \\
\text { hepatitis B than unvaccinated } \\
\text { colleagues } \\
\text { - Training on blood borne } \\
\text { viruses had little effect on } \\
\text { prison officers' knowledge or } \\
\text { perception of blood borne } \\
\text { viral infections }\end{array}$ \\
\hline [81] & 2006 Golden & $\begin{array}{l}\text { Dublin Single-site } \\
\text { Hospital }\end{array}$ & $\begin{array}{l}\text { HCV infected patients } \\
\text { awaiting treatment } \\
(87 ; m=64 ; \text { PWID = } \\
46 \%)\end{array}$ & & $\begin{array}{l}\text { Prevalence of illness- } \\
\text { related stigma and } \\
\text { mood disorders using } \\
\text { standardised } \\
\text { instruments }\end{array}$ & $\begin{array}{l}\text { - Fear of disclosure combined } \\
\text { with social isolation and } \\
\text { social rejection } \\
\text { - Stigma was higher in those } \\
\text { in manual occupations and } \\
\text { the unemployed than in } \\
\text { those in non-manual } \\
\text { occupation } \\
\text { - High levels of disease- } \\
\text { associated stigma in those } \\
\text { with disease associated with } \\
\text { IDU and iatrogenic disease } \\
\text { caused by transfusion or anti- } \\
\text { D blood products } \\
\text { - Stigma was associated with } \\
\text { depression (OR =1.4) } \\
\text { - Stigma was also associated } \\
\text { with poorer work and social } \\
\text { adjustment, lower } \\
\text { acceptance of illness, higher } \\
\text { subjective levels of } \\
\text { symptoms and greater } \\
\text { subjective impairment of } \\
\text { memory and concentration. } \\
\text { These associations were } \\
\text { replicated in the non- } \\
\text { depressed subsample. } \\
\text { - Strong link between stigma } \\
\text { and well-being in hepatitis C }\end{array}$ \\
\hline [83] & $\begin{array}{l}2010 \text { Swan } \\
\text { et al }\end{array}$ & $\begin{array}{l}\text { Dublin Multi-site (7) } \\
\text { Drug treatment clinic (2) } \\
\text { GP (1) Community drop }\end{array}$ & PWID $(36 ; m=28)$ & $2007-2008$ & $\begin{array}{l}\text { In-depth one-to-one in- } \\
\text { terviews using grounded } \\
\text { theory methodology }\end{array}$ & $\begin{array}{l}\text { Anti-HCV }=91 \% \text { HIV co- } \\
\text { infected }=11 \% \text { Barriers to HCV } \\
\text { screening and treatment: }\end{array}$ \\
\hline
\end{tabular}


Table 6 Qualitative research reporting on patients' and health providers' experiences (Continued)

\begin{tabular}{|c|c|c|c|c|c|c|}
\hline & $\begin{array}{l}\text { Date and } \\
\text { author }\end{array}$ & Setting & Sample (n) & Data collection & Design & Main results \\
\hline & & $\begin{array}{l}\text { in (1) Hepatology (2) ID } \\
\text { clinic (1) }\end{array}$ & & & & $\begin{array}{l}\text { - Perceptions of HCV infection } \\
\text { as relatively benign } \\
\text { - fear of investigations and } \\
\text { treatment including liver } \\
\text { biopsy and interferon } \\
\text { - feeling well } \\
\text { - limited knowledge of testing } \\
\text { sites } \\
\text { - not being referred for } \\
\text { specialist investigations } \\
\text { - ineligibility for treatment } \\
\text { - competing priorities } \\
\text { (employment, education, and } \\
\text { addiction). } \\
\text { Facilitators to HCV screening } \\
\text { and treatment: } \\
\text { - relationships with health care } \\
\text { providers } \\
\text { - trust in providers } \\
\text { - concern for the service-user } \\
\text { - continuity of care } \\
\text { - education on HCV infection, } \\
\text { investigations, and treatment } \\
\text { - becoming symptomatic } \\
\text { - responsibilities for children } \\
\text { - wanting to move on from } \\
\text { drug use }\end{array}$ \\
\hline \multirow[t]{2}{*}{ [84] } & $\begin{array}{l}\text { Whitaker et al. } \\
2011\end{array}$ & Dublin & $\begin{array}{l}\text { Drug using sex } \\
\text { workers }(35 ; m=4)\end{array}$ & & $\begin{array}{l}\text { One-to-one in-depth } \\
\text { interviews }\end{array}$ & $\begin{array}{l}\text { Multiple layers of stigma were } \\
\text { reported, linked to sex work, } \\
\text { drug use (including IDU) and } \\
\text { having contracted HIV or HCV } \\
\text { - Stigma was powerfully } \\
\text { reinforced by the language } \\
\text { routinely used by health } \\
\text { professionals. }\end{array}$ \\
\hline & & & & & & $\begin{array}{l}\text { - To improve the } \\
\text { effectiveness of harm- } \\
\text { reduction interventions, it is } \\
\text { recommended that service } \\
\text { providers change their lan- } \\
\text { guage, in particular in rec- } \\
\text { ognition of the human } \\
\text { dignity of these clients, but } \\
\text { also to help attract and re- } \\
\text { tain drug users in services, } \\
\text { and to help reduce the un- } \\
\text { acceptable mortality levels } \\
\text { among drug users. }\end{array}$ \\
\hline \multirow[t]{6}{*}{ [73] } & $\begin{array}{l}2017 \text { Crowley } \\
\text { et al }\end{array}$ & $\begin{array}{l}\text { Dublin Single site } \\
\text { Community drug } \\
\text { treatment centre }\end{array}$ & $\begin{array}{l}\text { PWID attending } \\
\text { community fibroscan } \\
\text { clinic (68) }\end{array}$ & 2017 & $\begin{array}{l}\text { Mixed methods } \\
\text { Researcher administered } \\
\text { questionnaire }\end{array}$ & $\begin{array}{l}\text { Attendance }=90 \% \\
\text { - high levels of unemployment } \\
(90 \%) \text { and homelessness } \\
(40 \%)\end{array}$ \\
\hline & & & & & & $\begin{array}{l}\text { - higher fibroscan scores (> } \\
8.5 \mathrm{Kpa} \text { ) were associated } \\
\text { with longer time since } \\
\text { diagnosis ( } p=0.016) \text {. }\end{array}$ \\
\hline & & & & & & $\begin{array}{l}\text { Patient identified barriers to } \\
\text { engagement: }\end{array}$ \\
\hline & & & & & & - alcohol and drug use \\
\hline & & & & & & $\begin{array}{l}\text { - fear of HCV treatment and } \\
\text { liver biopsy }\end{array}$ \\
\hline & & & & & & • imprisonment \\
\hline
\end{tabular}


Table 6 Qualitative research reporting on patients' and health providers' experiences (Continued)

\begin{tabular}{|c|c|c|c|c|c|c|}
\hline & $\begin{array}{l}\text { Date and } \\
\text { author }\end{array}$ & Setting & Sample (n) & Data collection & Design & Main results \\
\hline & & & & & & - distance to hospital \\
\hline & & & & & & $\begin{array}{l}\text { - early morning } \\
\text { appointments. }\end{array}$ \\
\hline & & & & & & $\begin{array}{l}\text { Patient identified enablers: } \\
\text { • afternoon appointments }\end{array}$ \\
\hline & & & & & & $\begin{array}{l}\text { - enhanced prison referral } \\
\text { mechanisms into the } \\
\text { community Fibroscan unit }\end{array}$ \\
\hline & & & & & & $\begin{array}{l}\text { - location of services within } \\
\text { the addiction treatment and } \\
\text { detoxification services }\end{array}$ \\
\hline \multirow[t]{6}{*}{ [79] } & \multirow{6}{*}{$\begin{array}{l}2017 \mathrm{Ni} \\
\text { Cheallaigh } \\
\text { et al. }\end{array}$} & \multirow{6}{*}{$\begin{array}{l}\text { National Multi-site Com- } \\
\text { munity drug treatment } \\
\text { centres, homeless hos- } \\
\text { tels, GPs }\end{array}$} & \multirow{6}{*}{$\begin{array}{l}\text { Study sites: Pilot sites } \\
\text { (4): } 2 \text { Dublin based } \\
\text { community drug } \\
\text { treatment centres, } 1 \\
\text { Waterford based; } 1 \\
\text { Dublin based } \\
\text { homeless hostel } 10 \\
\text { interviewees from } 8 \\
\text { sites at baseline. } 6 \\
\text { participants in pilot } \\
\text { programme at study } \\
\text { completion }\end{array}$} & \multirow[t]{6}{*}{ Mar-Oct 2015} & \multirow[t]{6}{*}{ Purposive sampling } & $\begin{array}{l}\text { Estimated HCV prevalence in } \\
\text { GP practices }=1-10 \%\end{array}$ \\
\hline & & & & & & $\begin{array}{l}\text { Estimated chronic prevalence } \\
\text { in pilot sites }=15-75 \%\end{array}$ \\
\hline & & & & & & $\begin{array}{l}\text { - PWID were identified as } \\
\text { the main group facing } \\
\text { barriers to accessing } \\
\text { specialist HCV care. }\end{array}$ \\
\hline & & & & & & $\begin{array}{l}\text { - State-employed doctors } \\
\text { and nurses were successfully } \\
\text { recruited to participate in } \\
\text { the project. }\end{array}$ \\
\hline & & & & & & $\begin{array}{l}\text { - GPs did not participate, } \\
\text { due mainly to a lack of time } \\
\text { and the absence of } \\
\text { reimbursement for } \\
\text { participation. }\end{array}$ \\
\hline & & & & & & $\begin{array}{l}\text { - Benefits to practitioners and } \\
\text { their patients were reported. } \\
\text { Participants expressed interest } \\
\text { in continued engagement } \\
\text { with similar multidisciplinary, } \\
\text { multisite educational } \\
\text { interventions in the future. }\end{array}$ \\
\hline
\end{tabular}

The majority of the studies are epidemiological and report on HCV prevalence in both cohorts. This scoping review found that Ireland has low rates of HCV infection in the general population compared to other European countries [5, 27, 86, 87]. The most up to data (residual sera study) showed a reduced prevalence compared to a 2012 mathematical modelling study [6, 9]. The different rates could be explained by the differing methodologies or by a reduction in new infections. The absence of a population prevalence study makes it difficult to have a true $\mathrm{HCV}$ population estimate and impacts on the development of strategies to identify the undiagnosed population $[6,88]$.

This review found that IDU is the most common risk factor for HCV acquisition in Ireland and that the prevalence of $\mathrm{HCV}$ infection in Irish prisoners and PWUD is much higher than the general population. The prisonbased studies included in the review found a reducing HCV prevalence with the most recent study (2014) reporting a prevalence of $13 \%$ [13]. This is much lower than the global estimates of $25 \%$ [11] but similar to other European country estimates [5]. The prevalence of $\mathrm{HCV}$ in all groups of PWUD and PWID is over 50\%. Again, this is in keeping with other global and European estimates for this group $[2,5]$. The majority of the studies included in the review are over a decade old, only include drug users on OST and all but two are Dublin based. There is a paucity of up to date literature on HCV prevalence in PWUD from outside Dublin and none at all on PWUD not on OST. A small number of studies reported on rates of chronic infection, but no study reported on the population based chronic $\mathrm{HCV}$ prevalence. This is a significant deficit in the literature as it does not allow for accurate estimates of untreated HCV infections and re-infections [89].

This review also found low levels of RNA testing for those identified as anti-HCV positive. Consideration 
should be given too adapting a reflex-RNA testing approach to HCV screening in Ireland [10]. This has the potential to reduce the number of bloods required in a group where venepuncture can be difficult and an indemnified barrier to engagement in $\mathrm{HCV}$ care [90]. As Ireland scales up $\mathrm{HCV}$ screening and treatment it is important that accurate data on levels of active $\mathrm{HCV}$ infection is available to optimise and evaluate the effectiveness of the national HCV strategy.

This review identified significant strategy, policy and guideline documents published over the last 14 years related to HCV. These provide a broader national context in which to interpret the literature and allow for comparisons to made with international and European strategies aimed at HCV elimination [27, 28]. However, it is concerning that the national strategy was published in 2012 and much of its content relates to interferon-based treatments and related challenges [14]. While the NHCTP provides up to date recommendations on $\mathrm{HCV}$ treatment [26], a new strategy is required to support the upscaling of $\mathrm{HCV}$ care, in particular, its movement into community addiction services and primary care. The national screening guidelines provide a useful guide to active HCV case identification [10]. These guidelines need to be underpinned with adequate resources and an evaluation to measure their effectiveness in identifies what is considered to be a significant level of hidden $\mathrm{HCV}$ infection in Ireland [6].

A handful of studies in this review report on treatment uptake and outcomes and on the lived experience of Irish HCV infected prisoners and PWUD [43, 44, 57, 83]. The evidence suggests poor uptake by HCV infected community PWUD with hospital-based services. This review also identified the many barriers related to $\mathrm{HCV}$ treatment uptake by this group [73, 83]. Many of these barriers are associated with previous interferon-based treatment and will be eliminated by the availability of DAA [29, 30]. This review also reports a number of facilitators to $\mathrm{HCV}$ engagement by Irish PWUD including the movement of HCV treatment out of specialised hospital services into community OST clinics. The success of this approach has been reported previously in the literature [91, 92] and is now the strategy being adapted the NHCTP [26]. This review found that treatment outcomes were not negatively impacted by patients having a history of IDU, however active drug use was identified as having a negative impact on treatment engagement. These findings need to be viewed with caution since they are related to interferon-based treatments [77]. Many patients were excluded from accessing treatment based on; a history of active IDU, excess alcohol or other drug use, concerns regarding relapse or mental health issues [91, 93]. Treatment was also only provided in specialist hospital services and only imitated after many hospital visits. This ensured that only the most stable and compliant PWUD accessed treatment. Broadening treatment eligibility. Increasing treatment locations and the use of short acting pangenotypic DAA will engage many less stable PWUD with HCV care [29, 30]. It is important the real-world data is available to monitor SVR post treatment and re-infection rates [94]. Similar to other published studies this review found SVR rates in prisoners equal or better that in the community $[95,96]$. But challenges remain in screening and engaging more prisoners in HCV care [97]. This review found no studies reporting on prison-based barriers and facilitators to $\mathrm{HCV}$ care.

There is very little data available on the levels of $\mathrm{HCV}$ related liver disease in PWID and prisoners [98]. Where available, the evidence supports increasing levels of morbidity and mortality in these groups $[98,99]$. This review found that $\mathrm{HCV}$ infection was associated with increased mortality and that problem alcohol use was common among HCV infected PWUD. Irish epidemiological studies report that there is an aging cohort of $\mathrm{HCV}$ infected PWUD, the majority having the infection for over 10 years. It is reasonable to expect that there is significant related liver disease in this cohort. While this group where initially prioritised for DDA treatment there is no data on how many of this high-risk group remain untreated. Studies on rates of $\mathrm{HCV}$ related liver disease and treatment uptake in this high-risk groups are required to ensure that are treatment strategies are successful in reducing $\mathrm{HCV}$ related morbidity and mortality.

Noticeable gaps identified in the literature on $\mathrm{HCV}$ in Irish prisoners and PWUD was the lack of studies, on strategies to prevent $\mathrm{HCV}$ infection and rates of incident infection in both groups. Ireland has a well-established network of harm reduction services including OST and needle exchange programs which are known to be effective in reducing $\mathrm{HCV}$ infection if provided with adequate coverage $[100,101]$. However, there is no data available on their effectiveness in an Irish setting. Monitoring the rates of new infections will provide an indicator to the success of harm reduction services and the impact of treatment as prevention as more people are successfully treated with SVR.

\section{Conclusion}

This review summarises the literature on $\mathrm{HCV}$ in Irish PWUD and prisoners. The findings show that in Ireland, $0.5 \%$ of the general population have chronic HCV infection (60\% undiagnosed), $13 \%$ of prisoners and over $50 \%$ of PWUD on OST have been exposed to HCV infection. People with a history of injecting heroin carry the greatest $\mathrm{HCV}$ disease burden in Ireland, with the majority having the infection for greater than 10 years. Increasing 
HCV related morbidity and mortality in this cohort, particularly in those with problem alcohol use is a concern. Irish PWUD engage poorly with hospital-based services and many barriers to HCV treatment uptake in this cohort have been identified. HCV treatment outcomes in Irish PWID is similar to other patient groups. In-reach hepatology services to Irish prisons has a positive impact on both uptake and successful completion of HCV treatment and its expansion to all prisons in Ireland should be considered. This review identified a range of policy and strategy documents that can inform national $\mathrm{HCV}$ screening, treatment and prevention programmes. A number of gaps in the literature were identified including; lack of reliable national prevalence data on untreated $\mathrm{HCV}$ infection (general population, PWUD and prisoners), accurate estimates of $\mathrm{HCV}$ related disease burden, $\mathrm{HCV}$ incidence infection in both PWUD and prisoners, barriers and facilitators to prisoners engaging with HCV services and HCV treatment uptake and outcomes in both groups. The lack of HCV epidemiolocal data on PWUD outside of Dublin and those not on OST is a concern. It is also important that policy and strategy documents are kept current to reflect international evidence-based practice and are informed by more accurate HCV surveillance data. This review is timely as Ireland scales up community-based HCV screening and treatment and gathers the available literature on $\mathrm{HCV}$ in Irish PWUD and prisoners. It is a useful starting point and can be used as a baseline to measure our efforts to eliminate $\mathrm{HCV}$ infection as a major Irish public health problem.

\section{Additional file}

Additional file 1: Search strategy and excluded studies. This file shows an example of the search strategy used for PubMed and the bases on which studies were excluded from the Scoping Review. (DOCX $25 \mathrm{~kb}$ )

\section{Abbreviations}

BBV: Blood-borne virus; Cl: Confidence interval; CTL: Central Treatment List; DAA: Direct-acting antivirals; DOH: Department of Health; DOJ: Department of Justice; EMCDDA: European Monitoring Centre for Drugs and Drug Addiction; ESLD: End stage liver disease; GPs: General practitioners; HCC: Hepatocellular carcinoma; HCV: Hepatitis C Virus; HSE: Health Service Executive; HSPC: Health Surveillance Protection Centre; IDU: Injecting drug use; IPRT: Irish Penal Reform Trust; IPS: Irish Prison Service; MMT: Methadone maintenance treatment; NDTC: National Drug Treatment Centre; NHCTP: National Hepatitis C Treatment Programme; NVRL: National Virus Reference Laboratory; OR: Odds ratio; OST: Opioid substitution treatment; PWID: People who inject drugs; PWUD: People who use drugs; ROI: Republic of Ireland; SVR: Sustained virologic response

\section{Acknowledgements}

None.

\section{Authors' contributions}

Conception and design: DC, RM, WC, JSL, TMCH, MCVH. Acquisition of data: DC, RM, TMCH, Analysis and interpretation of data: DC, RM, TMCH, Drafting the manuscript: DC, Revising it critically for important intellectual content:
DC, RM, WC, JSL, TMCH, MCVH. All authors gave final approval of the version to be published.

Funding

This study was self-funded.

Availability of data and materials

Not applicable.

Ethics approval and consent to participate

Not applicable.

Consent for publication

Not applicable.

\section{Competing interests}

The authors declare that they have no competing interests.

\section{Author details}

${ }^{1}$ Irish College of General Practitioners, Dublin, Ireland. ${ }^{2}$ School of Medicine, University College, Dublin, Ireland. ${ }^{3}$ Mater Misericordiae University Hospital, Dublin, Ireland. ${ }^{4}$ Public Health Institute, Liverpool John Moores University, Liverpool, UK.

Received: 4 October 2018 Accepted: 26 June 2019

Published online: 08 August 2019

References

1. WHO 2017. Global Hepatitis Report 2017, World Health Organization. Geneva; 2017. http://www.who.int/hepatitis/publications/global-hepatitisreport2017/en/.

2. Degenhardt L, Peacock A, Colledge S, Leung J, Grebely J, Vickerman P, et al. Global prevalence of injecting drug use and sociodemographic characteristics and prevalence of HIV, HBV, and HCV in people who inject drugs: a multistage systematic review. Lancet Glob Heal. 2017;5:e1192-207.

3. Gower E, Estes C, Blach S, Razavi-Shearer K, Razavi H. Global epidemiology and genotype distribution of the hepatitis C virus infection. J Hepatol. 2014; 61:S45-57. https://doi.org/10.1016/j.jhep.2014.07.027.

4. Nelson PK, Mathers BM, Cowie B, Hagan H, Des Jarlais D, Horyniak D, et al. Global epidemiology of hepatitis $B$ and hepatitis $C$ in people who inject drugs: results of systematic reviews. Lancet. 2011;378:571-83. https://doi. org/10.1016/S0140-6736(11)61097-0.

5. Falla AM, Hofstraat SHI, Duffell E, Hahné SJM, Tavoschi L, Veldhuiizen IK Hepatitis B/C in the countries of the EU/EEA: a systematic review of the prevalence among at-risk groups. BMC Infect Dis. 2018;18:79.

6. Thornton L, Murphy N, Jones L, Connell J, Dooley S, Gavin S, et al. Determination of the burden of hepatitis $C$ virus infection in Ireland. Epidemiol Infect. 2012;140:1461-8. https://doi.org/10.1017/ S0950268811001920.

7. European Monitoring Centre for Drugs and Drug Addiction (EMCDDA). Hepatitis $C$ among drug users in Europe: epidemiology, treatment and prevention. Lisbon; 2016.

8. Chung RT, Davis GL, Jensen DM, Masur H, Saag MS, Thomas DL, et al. Hepatitis C guidance: AASLD-IDSA recommendations for testing, managing, and treating adults infected with hepatitis C virus. Hepatology. 2015;62:93254. https://doi.org/10.1002/hep.27950.

9. Garvey P, O'Grady B, Franzoni G, Bolger M, Irwin Crosby K, Connell J, et al. Hepatitis $C$ virus seroprevalence and prevalence of chronic infection in the adult population in Ireland: a study of residual sera, April 2014 to February 2016. Eurosurveillance. 2017;22:30579. https://doi.org/10.2807/1560-7917.ES. 2017.22.30.30579.

10. Department of Health. Hepatitis C Screening (NCEC National Clinical Guideline No. 15). Dublin; 2017. http://health.gov.ie/national-patient-safetyoffice/ncec/national-clinical-guidelines. Accessed 14 Mar 2018.

11. Larney S, Kopinski H, Beckwith CG, Zaller ND, Des JD, Hagan H, et al. Incidence and prevalence of hepatitis $C$ in prisons and other closed settings: results of a systematic review and meta-analysis. Hepatology. 2013; 58:1215-24. https://doi.org/10.1002/hep.26387.

12. Vescio MF, Longo B, Babudieri S, Starnini G, Carbonara S, Rezza G, et al. Correlates of hepatitis $C$ virus seropositivity in prison inmates: a meta- 
analysis. J Epidemiol Community Health. 2008;62:305-13. https://doi.org/10. 1136/jech.2006.051599.

13. Drummond A, Codd M, Donnelly N, McCausland D, Mehegan J, Daly L, et al. Study on the prevalence of drug use, including intravenous drug use, and blood-borne viruses among the Irish prisoner population. Dublin: BMJ Publishing Group Ltd; 2014. p. 138. https://doi.org/10.1136/jech-2015206256

14. Health Service Executive. National Hepatitis C Strategy 2011-2014. 2012. http://www.hse.ie/eng/services/news/newsarchive/2012archive/sept12/ HepCStrategy.html. Accessed 16 Mar 2018.

15. Health Protection Surveillance Centre. Report on Hepatitis C notifications quarters 3\&amp;4 2017 and annual summary 2017. Dublin; 2018.

16. Thornton L, Barry J, Long J, Allwright S, Bradley F, Parry JV. Comparison between self-reported hepatitis B, hepatitis C, and HIV antibody status and oral fluid assay results in lrish prisoners. Commun Dis Public Health. 2000;3:253-5 https://www. scopus.com/inward/record.uri?eid=2-s2.0-0034569144\%7B\&\%7DpartnerlD= 40\%7B\&\%7Dmd5=e2764a0909e70ffd637995b46febe822.

17. Smyth BP, Keenan E, $\mathrm{O}^{\prime}$ Connor JJ. Bloodborne viral infection in Irish injecting drug users. Addiction. 1998;93:1649-56.

18. Allwright $\mathrm{S}$, Bradley F, Long J, Barry J, Thornton L, Parry JV. Prevalence of antibodies to hepatitis B, hepatitis $C$, and HIV and risk factors in Irish prisoners: results of a national cross sectional survey. BMJ. 2000;321:78-82. https://doi.org/10.1136/BMJ.321.7253.78.

19. Carew AM, Murphy N, Long J, Hunter K, Lyons S, Walsh C, et al. Incidence of hepatitis $\mathrm{C}$ among people who inject drugs in Ireland. Hepatol Med Policy. 2016;2:7. https://doi.org/10.1186/s41124-017-0024-1.

20. ASECAP. Statistical bulletin 2016. 2016;XXV:1-96.

21. Hay G, Jaddoa A, Oyston J, Webster J, Claire M, Hout V. Estimating the Prevalence of Problematic Opiate Use in Ireland Using Indirect Statistical Methods. 2017.

22. Health Research Board. Drug treatment in Ireland 2010-2016. Dublin; 2016.

23. Van Hout MC, Crowley D, McBride A, Delargy I. Optimising treatment in opioid dependency in primary care: results from a national key stakeholder and expert focus group in Ireland. BMC Fam Pract. 2018;19:103.

24. Barry JM, Darker CD, Thomas DE, Allwright SPA, O'Dowd T. Primary medical care in irish prisons. 2010.

25. Comiskey CD, O'Sullivan K, Cronly J. Hazardous journeys to better places positive outcomes and negative risks associated with the care pathway before, during and after an admittance to the Dochas Centre, Mountjoy Prison. 2006.

26. Health Service Executive. National Hepatitis C Treatment Programme Ireland's Health Service. 2016. https://www.hse.ie/eng/about/who/ primarycare/hepcprogramme..html. Accessed 14 Mar 2018.

27. Public Health England. Hepatitis C in the UK 2017 Report. 2017.

28. Australian Government/Department of Health. Fourth National Hepatitis C strategy. 2014

29. Grebely J, Bruneau J, Bruggmann P, Harris M, Hickman M, Rhodes T, et al. Elimination of hepatitis $C$ virus infection among PWID: the beginning of a new era of interferon-free DAA therapy. Int J Drug Policy. 2017;47:26-33.

30. Burstow NJ, Mohamed Z, Gomaa Al, Sonderup MW, Cook NA, Waked I, et al. Hepatitis $C$ treatment: where are we now? International Journal of General Medicine. 2017;10:39-52. https://doi.org/10.2147/IJGM.S127689.

31. European Association for the Study of the Liver. EASL recommendations on treatment of Hepatitis C 2016. J Hepatol. 2017;66:153-94. https://doi.org/10. 1016/j.jhep.2016.09.001.

32. Thompson AJ. Australian recommendations for the management of hepatitis C virus infection: a consensus statement. Med J Aust. 2016;204:268-72.

33. World Health Organization. Guidelines for the screening care and treatment of persons with chronic Hepatitis C infection. Geneva; 2016. doi:ISBN 97892 41549615.

34. Arksey H, O'Malley L. Scoping studies: towards a methodological framework. Int J Soc Res Methodol Theory Pract. 2005;8:19-32. https://doi.org/10.1080/ 1364557032000119616

35. Levac D, Colquhoun H, O'Brien KK. Scoping studies: advancing the methodology. Implement Sci. 2010;5:69.

36. Smyth BP, O'Connor JJ, Barry J, Keenan E. Retrospective cohort study examining incidence of HIV and hepatitis $\mathrm{C}$ infection among injecting drug users in Dublin. J Epidemiol Community Health. 2003;57:310-1.

37. Grogan L, Tiernan M, Geogeghan N, Smyth B, Keenan E. Bloodborne virus infections among drugs users in Ireland: a retrospective cross-sectional survey of screening, prevalence, incidence and hepatitis B immunisation uptake. Ir J Med Sci. 2005;174:14-20. https://doi.org/10.1007/BF03169123.
38. Long J, Allwright S, Barry J, Reynolds SR, Thornton L, Bradley F, et al. Prevalence of antibodies to hepatitis B, hepatitis C, and HIV and risk factors in entrants to Irish prisons: a national cross sectional survey. Br Med J. 2001; 323:1209-12. https://doi.org/10.1136/bmi.323.7323.1209.

39. Fitzgerald M, Barry J, O'Sullivan P, Thornton L. Blood-borne infections in Dublin's opiate users. Ir J Med Sci. 2001;170:32-4.

40. Noonan A, Kavanagh P, Sweeney B. Drug users' failure to modify alcohol consumption in response to hepatitis C. Ir J Psychol Med. 2009;26:27-31. https://doi.org/10.1017/S0790966700000100.

41. Moloney J. Hepatitis C: Lower prevalence in young persons' addiction treatment programme than in adult programmes. 2004. https://www. drugsandalcohol.ie/6961\%. Accessed 14 July 2018.

42. Cullen W, Bury G, Barry J, O'Kelly FD. Hepatitis C infection among drug users attending general practice. Ir J Med Sci. 2003;172:123-7 http://www.ncbi. nlm.nih.gov/entrez/query.fcgi? cmd=Retrieve\&db=PubMed\&dopt= Citation\&list_uids $=14700114$.

43. Cullen W, Kelly Y, Stanley J, Langton D, Bury G. Experience of hepatitis C among current or former heroin users attending general practice. Ir Med J. 2005;98:73-4.

44. Cullen W, Stanley J, Langton D, Kelly Y, Bury G. Management of hepatitis C among drug users attending general practice in Ireland: baseline data from the Dublin area Hepatitis C in general practice initiative. Eur J Gen Pract. 2007;13:5-12.

45. Fielding JF, Shattock AG, Doyle GD, Kelly MG. Non-a non-B hepatitis in parenteral drug abusers. Ir Med J. 1983;76:414-5 http://www.ncbi.nlm.nih. gov/pubmed/6417045

46. Smyth BP, McMahon J, O'Connor JJ, Ryan J. HCV screening [3]. Ir Med J. 2000;93:154-5.

47. Smyth BP, Keenan E, O'Connor JJ. Evaluation of the impact of Dublin's expanded harm reduction programme on prevalence of hepatitis $C$ among short-term injecting drug users. J Epidemiol Community Health. 1999;53: 434-5.

48. Smyth R, Keenan E, Dorman A, O'Connor J. Hepatitis C infection among injecting drug users attending the National Drug Treatment Centre. Ir J Med Sci. 1995;164:267-8 http://www.ncbi.nlm.nih.gov/entrez/query.fcgi?cmd= Retrieve\&db=PubMed\&dopt=Citation\&list_uids $=8522425$.

49. Kavanagh P, Moloney J, Quinn C, O'Kelly E, McCormick PA. High morbidity expected from cirrhosis in injecting drug users. Ir Med J. 2003:96:303-5.

50. Keating S, Coughlan S, Connell J, Sweeney B, Keenan E. Hepatitis C viral clearance in an intravenous drug-using cohort in the Dublin area. Ir J Med Sci. 2005;174:37-41.

51. Smyth BP, Barry J, Keenan E. Irish injecting drug users and hepatitis C: the importance of the social context of injecting. Int J Epidemiol. 2005; 34:166-72.

52. O'Kelly FD, O'Kelly CM. The natural history of injecting drug use: a 25-year longitudinal study of a cohort of injecting drug users in inner city Dublin. Ir J Med Sci. 2012;181:541-8. https://doi.org/10.1007/s11845-012-0814-9.

53. Healy CM, Cafferkey MT, Conroy A, Dooley S, Hall WW, Beckett M, et al. Outcome of infants born to hepatitis C infected women. IrJMedSci. 2001; 170:103-6.

54. O'Carroll A, O'Reilly F. Health of the homeless in Dublin: has anything changed in the context of Ireland's economic boom? Eur J Pub Health. 2008;18:448-53. https://doi.org/10.1093/eurpub/ckn038.

55. Smyth BP, Keenan $\mathrm{E}, \mathrm{O}^{\prime}$ Connor JJ. Assessment of hepatitis $\mathrm{C}$ infection in injecting drug users attending an addiction treatment clinic. Ir J Med Sci. 2000;169:129-32. https://doi.org/10.1007/BF03166917.

56. Cullen W, Stanley J, Langton D, Kelly Y, Staines A, Bury G. Hepatitis C infection among injecting drug users in general practice: a cluster randomised controlled trial of clinical guidelines' implementation. $\mathrm{Br} J \mathrm{Gen}$ Pract. 2006;56:848-56.

57. Galander T, Rosalim J, Betts-Symonds G, Scully M. A survey of patients on methadone programmes in Wheatfield Prison, Dublin, Ireland. Heroin Addict Relat Clin Probl. 2014;16:17-22. http://www. heroinaddictionrelatedclinical problems.org/download-magazine. php?idrivista=R0000055\%0Ahttp://libaccess.mcmaster.ca/login?url=http:// ovidsp.ovid.com/ovidweb.cgi?T=JS\&CSC=Y\&NEWS $=$ N\&PAGE=fulltext\&D= emed16\&AN=600473788\%0Ahttp://sfx.scholarsportal.in.

58. Ryan $\mathrm{H}$, Ryan $\mathrm{S}$. Increasing incidence of hepatitis $\mathrm{C}$ among intravenous drug users in HSE mid-west. NIHS Res Bull. 2014;7:32.

59. Keegan D, Crowley D, Laird E, VHM C. Prevalence and risk factors for hepatitis $C$ viral infection amongst a cohort of irish drug users attending a drug treatment 
Centre for agonist opioid treatment (AOT). Heroin Addict Relat Clin Probl. 2017; 19:47-56 http://www.drugsandalcohol.ie/25815/. Accessed 3 Dec 2017.

60. Murtagh R, Swan D, O'Connor E, McCombe G, Murphy C, Lambert J, et al. Hepatitis $\mathrm{C}$ management among patients receiving opioid substitution treatment in general practice in Ireland. Ir J Med Sci 2017;186:S466. doi: https://doi.org/10.1007/s11845-017-1711-z LK - http://jg6am9xs3s.search. serialssolutions.com/?sid=EMBASE\&issn=18634362\&id=doi:10. 1007\%2Fs11845-017-1711-z\&atitle=Hepatitis+C+management+among+ patients+receiving+opioid+substitution+treatment+in+general+practice+ in+Ireland\&stitle=|r.+J.+Med. + Sci.\&title=|rish+Journal+of+Medical + Science\&volume $=186 \&$ issue $=12 \&$ spage $=\$ 466 \&$ epage $=$ \&aulast $=$ Murtagh\&aufirst=R.\&auinit=R.\&aufull=Murtagh+R.\&coden=\&isbn=\&pages= S466-\&date $=2017$ \&auinit $1=R \&$ auinitm $=$.

61. O'Connor G, McGinty T, Yeung SJ, O'Shea D, Macken A, Brazil E, et al. Crosssectional study of the characteristics, healthcare usage, morbidity and mortality of injecting drug users attending an inner city emergency department. Emerg Med J. 2014;31:625-9.

62. McCormick PA, Elrayah E, Hughes B, Schmidt D, Moloney J. Single liver stiffness measurement predicts liver-related mortality in chronic hepatitis $\mathrm{C}$. Aliment Pharmacol Ther. 2014;39:1438-9.

63. McCombe G, Henihan AM, Leahy D, Klimas J, Lambert JS, Cullen W. Commentary on Zeremski et al. (2016): improvements in HCV-related knowledge among substance users on opioid agonist therapy after an educational intervention. J Addict Med. 2016;10:363-4. https://doi.org/10. 1097/ADM.0000000000000244.

64. Allwright S, Bradley F, Long J, et al. Prevalence of antibodies to hepatitis B, hepatitis $C$, and HIV and risk factors in Irish prisoners: results of a national cross sectional survey. Br Med J. 2000;321:78-82.

65. Long J, Allwright S, Barry J, Reynolds SR, Thornton L, Bradley F, et al. Prevalence of antibodies to hepatitis $B$, hepatitis $C$, and HIV and risk factors in entrants to Irish prisons: a national cross sectional survey commentary: efficient research gives direction on prisoners' and the wider public health---except in England and. Bmj. 2001;323:1209. https:/doi.org/10.1136/bmj.323.7323.1209.

66. Eastern Regional Health Authority; Hepatitis C Scientific Advisory Group; Bloodborne virus forum. Hepatitis $\mathrm{C}$ in the eastern regional health authority: results of a multiagency consultation event. Dublin; 2004

67. Barry J, Bourke M, Buckley M, Coughlan B, Crowley D, Cullen W, et al. Hepatitis $C$ among drug users: consensus guidelines on management in general practice. Ir J Med Sci. 2004;173:145-50 http://www.ncbi.nlm.nih.gov/ pubmed/15693384.

68. Department of Health. Public Health Plan for the Pharmaceutical Treatment of Hepatitis C. 2014. http://health.gov.ie/wp-content/uploads/2015/07/FinalPublic-Health-Plan-for-the-Pharmaceutical-Treatment-of-Hep-C-Final-CopyCirculated-July-2015.pdf. Accessed 13 June 2018.

69. Health Service Executive. Clinical Guidelines for Opioid Substitution Treatment. Dublin; 2017. http://hse.ie/eng/services/publications/Primary/clinicalguidelines-for-opioid-substitution-treatment.pdf. Accessed 13 June 2018.

70. Irish Prison Service. Irish Prison Service Health Care Standards. 2011. http:/www. irishprisons.ie/images/pdf/hc standards 2011.pdf. Accessed 13 June 2018.

71. Lines R. From equivalence of standards to equivalence of objectives: the entitlement of prisoners to health care standards higher than those outside prisons. Int J Prison Health. 2006;2:269-80. https://doi.org/10.1080/ 17449200601069676.

72. Long J, Lynn E, Keating J. Blood-borne viral infections among injecting drug users in Ireland, 1995 to 2005. Drug Misuse Research Division [of] the Health Research Board; 2006.

73. Crowley D, Cullen W, Laird E, Lambert JS, Mc Hugh T, Murphy C, et al. Exploring patient characteristics and barriers to Hepatitis $C$ treatment in patients on opioid substitution treatment attending a community based fibro-scanning clinic. J Transl Intern Med. 2017;5:112-9. https://doi.org/10. 1515/jtim-2017-0017.

74. Kieran J, Dillon A, Farrell G, Jackson A, Norris S, Mulcahy F, et al. High uptake of hepatitis $C$ virus treatment in HIV/hepatitis $C$ virus co-infected patients attending an integrated HIV/hepatitis C virus clinic. Int J STD AIDS. 2011;22: 571-6. https://doi.org/10.1258/ijsa.2011.010416.

75. Lowry DJ, Ryan JD, Ullah N, Kelleher TB, Crowe J. Hepatitis C management Eur J Gastroenterol Hepatol. 2011;23:32-40. https://doi.org/10.1097/MEG. Ob013e3283414122.

76. Hopkins S, Lambourne J, Farrell G, McCullagh L, Hennessy M, Clarke S, et al. Role of individualization of hepatitis C virus (HCV) therapy duration in HIV/ HCV-coinfected individuals. HIV Med. 2006;7:248-54.
77. Elsherif O, Bannan C, Keating S, McKiernan S, Bergin C, Norris S. Outcomes from a large 10 year hepatitis $C$ treatment programme in people who inject drugs: no effect of recent or former injecting drug use on treatment adherence or therapeutic response. PLoS One. 2017;12:e0178398.

78. McKiernan S. HCV screening and Treatmen in prison; an Irish perspective. Dublin. 2018.

79. Ní Cheallaigh C, O'Leary A, Keating S, Singleton A, Heffernan S, Keenan E, et al. Telementoring with project ECHO: a pilot study in Europe. BMJ Innov. 2017;3:144-51. https://doi.org/10.1136/bmjinnov-2016-000141.

80. Goulding C, O'Connell P, Murray FE. Prevalence of fibromyalgia, anxiety and depression in chronic hepatitis $C$ virus infection: relationship to RT-PCR status and mode of acquisition. Eur J Gastroenterol Hepatol. 2001;13:507-11.

81. Golden J, Conroy RM, Marie O'Dwyer A, Golden D, Hardouin JB. Illness-related stigma, mood and adjustment to illness in persons with hepatitis C. Soc Sci Med. 2006;63:3188-98. https://doi.org/10.1016/j.socscimed.2006.08.005.

82. Golden J, O'Dwyer AM, Conroy RM. Depression and anxiety in patients with hepatitis C: prevalence, detection rates and risk factors. Gen Hosp Psychiatry. 2005;27:431-8. https://doi.org/10.1016/j.genhosppsych.2005.06.006.

83. Swan D, Long J, Carr O, Flanagan J, Irish H, Keating S, et al. Barriers to and facilitators of Hepatitis $C$ testing, management, and treatment among current and former injecting drug users: a qualitative exploration. AIDS Patient Care STDs. 2010;24:753-62. https://doi.org/10.1089/apc.2010.0142.

84. Whitaker T, Ryan P, Cox G. Stigmatization among drug-using sex workers accessing support services in Dublin. Qual Health Res. 2011;21:1086-100.

85. Dillon B, Allwright S. Prison officers' concerns about blood borne viral infections. Howard J Crim Justice. 2005;44:29-40. https://doi.org/10.1111/j. 1468-2311.2005.00353.x.

86. Blach S, Zeuzem S, Manns M, Altraif I, Duberg AS, Muljono DH, et al. Global prevalence and genotype distribution of hepatitis $C$ virus infection in 2015: a modelling study. Lancet Gastroenterol Hepatol. 2017;2:161-76.

87. Hope VD, Eramova I, Capurro D, Donoghoe MC. Prevalence and estimation of hepatitis B and C infections in the WHO European region: a review of data focusing on the countries outside the European Union and the European free trade association. Epidemiol Infect. 2014;142:270-86.

88. WHO Europe. Hepatitis $C$ in the WHO European Region. 2015;943 July: $1-110$.

89. Westbrook RH, Dusheiko G. Natural history of hepatitis C. J Hepatol. 2014;61: S58-68. https://doi.org/10.1016/j.jhep.2014.07.012.

90. Harris $\mathbf{M}$, Rhodes $\mathrm{T}$. Venous access and care: harnessing pragmatics in harm reduction for people who inject drugs. Addiction. 2012;107:1090-6.

91. Howes N, Lattimore S, Irving WL, Thomson BJ. Clinical care pathways for patients with hepatitis $C$ : reducing critical barriers to effective treatment. Open Forum Infect Dis. 2016;3:ofv218. https://doi.org/10.1093/ofid/ofv218.

92. Zhou K, Fitzpatrick T, Walsh N, Kim JY, Chou R, Lackey M, et al. Interventions to optimise the care continuum for chronic viral hepatitis: a systematic review and meta-analyses. Lancet Infect Dis. 2016;16:1409-22. https://doi. org/10.1016/S1473-3099(16)30208-0.

93. Roose RJ, Cockerham-Colas L, Soloway I, Batchelder A, Litwin AH. Reducing barriers to Hepatitis $C$ treatment among drug users: an integrated Hepatitis $\mathrm{C}$ peer education and support program. J Health Care Poor Underserved. 2014;25:652-62. https://doi.org/10.1353/hpu.2014.0096.

94. Martin NK, Vickerman P, Dore GJ, Hickman M. The hepatitis C virus epidemics in key populations (including people who inject drugs, prisoners and MSM): the use of direct-acting antivirals as treatment for prevention. Curr Opin HIV AIDS. 2015;10:374-80. https://doi.org/10.1097/COH. 0000000000000179

95. Aspinall EJ, Mitchell W, Schofield J, Cairns A, Lamond S, Bramley P, et al. A matched comparison study of hepatitis $C$ treatment outcomes in the prison and community setting, and an analysis of the impact of prison release or transfer during therapy. J Viral Hepat. 2016;23:1009-16. https://doi.org/10. 1111/jvh.12580.

96. Rice JP, Burnett D, Tsotsis H, Lindstrom MJ, Cornett DD, Voermans $\mathrm{P}$, et al. Comparison of hepatitis $C$ virus treatment between incarcerated and community patients. Hepatology. 2012;56:1252-60. https://doi.org/10.1002/hep.25770.

97. Yap L, Carruthers S, Thompson S, Cheng W, Jones J, Simpson P, et al. A descriptive model of patient readiness, motivators, and hepatitis $C$ treatment uptake among Australian prisoners. PLoS One. 2014;9:e87564. https://doi.org/10.1371/journal.pone.0087564.

98. Smith DJ, Combellick J, Jordan AE, Hagan H. Hepatitis C virus (HCV) disease progression in people who inject drugs (PWID): a systematic review and meta-analysis. Int J Drug Policy. 2015;26:911-21. 
99. Hajarizadeh B, Grebely J, Dore GJ. Epidemiology and natural history of HCV infection. Nat Rev Gastroenterol Hepatol. 2013;10:553-62.

100. Wiessing L, Ferri M, Běláčková V, Carrieri P, Friedman SR, Folch C, et al. Monitoring quality and coverage of harm reduction services for people who use drugs: a consensus study. Harm Reduct J. 2017;14:19.

101. Allen EJ, Palmateer NE, Hutchinson SJ, Cameron S, Goldberg DJ, Taylor A. Association between harm reduction intervention uptake and recent hepatitis $C$ infection among people who inject drugs attending sites that provide sterile injecting equipment in Scotland. Int J Drug Policy. 2012;23. 346-52. https://doi.org/10.1016/j.drugpo.2012.07.006.

\section{Publisher's Note}

Springer Nature remains neutral with regard to jurisdictional claims in published maps and institutional affiliations.

Ready to submit your research? Choose BMC and benefit from:

- fast, convenient online submission

- thorough peer review by experienced researchers in your field

- rapid publication on acceptance

- support for research data, including large and complex data types

- gold Open Access which fosters wider collaboration and increased citations

- maximum visibility for your research: over $100 \mathrm{M}$ website views per year

At $\mathrm{BMC}$, research is always in progress.

Learn more biomedcentral.com/submissions 